\title{
Medya Okuryazarlığı Dersine İlişsin Öğrenci Tutumları ile Öğretmen ve Öğretmen Adayı Görüşlerinin Değerlendirilmesi*
}

\section{Studying Attitudes of Student and Opinions of Teacher and Teacher Candidate Regarding The Media Literacy Lesson}

\author{
Yasemin AKSU BEKTAŞ**, Mehmet ALVER***
}

Öz: Bu araştırmada, medya okuryazarlığı dersine ilişkin öğrenci tutumlarını belirlemek, öğretmen ile öğretmen adaylarının görüşlerinin tespit etmek amaçlanmıştır. Araştırmada, nicel ve nitel araştırma yöntemleri bir arada kullanıldığından çalışma karma yöntemle desenlenmiştir. Araştırmanın nicel boyutunda tutum ölçeği, nitel boyutunda ise görüşme formu kullanılmıştır. Araştırmanın nicel verilerinin toplandığı çalışma grubunu, 2017-2018 eğitim-öğretim yılında Giresun ilinde seçmeli medya okuryazarlığ dersinin verildiği 5 ortaokulda medya okuryazarlığı dersi alan 153 sekizinci sınıf öğrencisi ile medya okuryazarlığı dersini almayan 103 yedinci sınıf öğrencisi oluşturmaktadır. Toplamda 256 öğrenci araştırmaya katılmıştır. Nitel verilerinin toplandığı çalışma grubunu ise seçmeli medya okuryazarlığ dersinin verildiği okullarda görev yapan 5 sosyal bilgiler, 1 Türkçe öğretmeni ve Giresun Üniversitesi Eğitim Fakültesinde öğrenim gören 15 Türkçe ile 15 sosyal bilgiler öğretmen adayı oluşturmaktadır. Nicel verilerin analizinde SPSS programı kullanılmıştır. Nitel verilerin analizinde ise görüşmeler yoluyla toplanan veriler içerik analizi ile çözümlenmiştir. Çalışmanın bulgularından hareketle; medya okuryazarlığı dersini alan ve almayan öğrencilerin medyanın algılanma biçimi boyutuna yönelik tutumları arasında anlamlı bir fark olmadığı, öğrencilerin medya araçlarını tercih sıraları aynı olup sırasıyla internet, televizyon, dergi, gazete, radyoyu tercih ettikleri, internet tercihinde dersi alanların, dergi tercihinde ise dersi almayanların lehine anlamsal fark olduğu, medya okuryazarlığı dersinin gereksiz bir ders olarak algılandığı, derste medya okuryazarlığına ilişkin konuların işlenmediği, bu ders için ayrılan sürenin başka branş derslerinin tamamlayıcısı olarak kullanıldığı sonuçlarına ulaşılmıştır.

Anahtar Kelimeler: Medya, medya okuryazarlığı, Türkçe eğitimi, öğrenci tutumları, öğretmen görüşleri

\begin{abstract}
In order to understand these messages, human beings must know the language of media which is a means of transmission and become literate. In this study, since quantitative and qualitative research methods are used together, this research is designed with mixed method. Attitude scale was used in the quantitative dimension of the study and interview form was used in the qualitative dimension. The study group consisted of 153 eighth grade students who had taken media literacy courses in 5 secondary schools in which the elective media literacy course was given in Giresun in 2017-2018 academic year. A total of 256 students participated in the study. The working group where the qualitative data is collected is in the schools where elective media literacy course is given is consists of 5 social studies and 1 Turkish teacher and 15 social studies and 15 Turkish teacher candidates are in Giresun University Faculty of Education. SPSS program was used to analyze the quantitative data. In the analysis of qualitative data, data collected through interviews were analyzed by content analysis. Based on the findings of the study; There is no significant difference between the attitudes of the media literacy classes and the attitudes of the media towards the perception of the media, the students prefer the media tools in the same order and they prefer the Internet, television, magazine, newspaper, radio, It was concluded that there was a semantic difference, media literacy was perceived as an unnecessary course, subjects related to media literacy were not covered in the course, and that the time allocated for this course was used as a complement to other branch courses. Keywords: Media, media literacy, Turkish education, student attitudes, teacher opinions Giriş

\footnotetext{
* Bu çalışma, birinci yazarın ikinci yazarın danışmanlığında aynı adla hazırladığı yüksek lisans tezinden üretilmiştir. ** Bilim Uzman1, Giresun Üniversitesi, Sosyal Bilimler Enstitüsü, Giresun-Türkiye, ORCID: 0000-0003-0566-348X, e-posta:99yaseminaks99@gmail.com

*** Doç. Dr.,Giresun Üniversitesi, Eğitim Fakültesi, Giresun-Türkiye, ORCID: 0000-0003-4832-7363, e-posta: mehmetalver2806@gmail.com
} 
İnsanoğlu, yaratılışı gereği çevresinde olup biten olay, olgu, durum ve değişimleri algılamaya çalışan, bu değişimleri fark eden, yorumlayan ve bu değişimlerle ilgili çıkarımlarda bulunan bir varlıktır. İnsan ya kendisi deneyimleyerek ya da başka bir aracın aktarmasıyla evrendeki bu değişimi ve bu değişimin verdiği mesajları algılar duruma gelir. Bu noktada, insan algısını yönlendiren başlıca uyaranlar vardır. Bu uyaranlar bireyin yakın çevresi, ailesi, içinde yaşadığı toplum ve bütün bu olguları içinde barındıran medyadır.

Medya, kitle iletişiminin göz ardı edilemez bir bütünüdür ve "Her türlü bilgiyi insana ve topluma ileten, eğlendirme, bilgilendirme ve eğitme gibi sorumlulukları olan gazete, dergi, radyo, televizyon, internet gibi görsel, işitsel ve hem görsel hem de işitsel araçların tamamı" şeklinde tanımlanmaktadır (Aydeniz, 2012, s. 16). Başka bir ifadeyle medya; "gazete, radyo, televizyon ve internet uygulamaları gibi kitlesel iletişime olanak sağlayan ortamlar başta olmak üzere, kişiler arası iletişime de olanak sağlayan teknoloji ve uygulamaları kapsayan bir yapıdır" (Bilici, 2011, s. 5). Görüldüğü gibi medya denildiğinde akla her daim iç içe olduğumuz kitle iletişim araçları gelmektedir.

Günümüzde teknolojik gelişmelerle birlikte toplum olarak yediden yetmişe TV programları, internet, cep telefonu, sinema, radyo bültenleri gibi görsel ve işitsel çoklu ortam (multimedya) mesajlarına her zamankinden daha çok maruz kalınması, 21. yüzyıl insanı için medya okuryazarlığının hayati bir değer taşımasına neden olmaktadır. Çağın bu denli gelişmişlik düzeyi, dönemin getirdiği teknolojik yenilikler ve medya araçlarındaki çeşitlilik, bireylerin bu araçları anlayıp mesajlara cevap verme becerisine sahip olmalarını gerekli kılmaktadır. "Medya okuryazarlığı bağımsız medya yaratmak kadar, her medyanın hem gücünü hem sınırlarını anlamada kolaylık sağlaması bakımından insanların usta birer medya iletisi yaratıcısı ve üreticisi olmalarını hedeflemektedir" (Taşkıran Öncel, 2007, s. 91).

Medya okuryazarlı̆̆ kavramının ortaya çıkışı kitle iletişim araçlarının toplum üzerindeki etkilerinin araştırılmasına dayanmaktadır. "1930'lar ve 1940'ların başlarındaki bu çalışmaların temelini Harold Lasswell'in ileri sürdüğü Hipodermik İğne Kuramı oluşturmaktadır. Bu kurama göre insanlar, medyanın sürekli olarak iletilerini enjekte ettiği savunmasız bireyler olarak görülüyordu. Daha sonra yapılan çalışmalar etki araştırmalarından farklı olarak hedef kitle üzerinde yoğunlaşmaya başlamıştır. Kitle iletişim araçlarının insanlara ne yaptığı değil, bireylerin medyaya ne yaptığı, medyayı hangi amaçlar için kullandığı araştırılmaya çalışılmıştır. Medya okuryazarlığı da buna bağlı bir anlayışla ele alınmıştır" (İnceoğlu, 2005, s. 15).

Medya okuryazarlığı ile ilgili çeşitli tanımlar yapılmıştır. İnceoğlu'na (2005, s. 19) göre medya okuryazarlığı, "yazılı ve yazılı olmayan farklı formatlardaki (televizyon, video, sinema, reklamlar, internet vs.) iletilere erişim ve bu iletileri çözümleme, değerlendirme ve iletme yeteneği”'dir. Tokgöz'e (2010, s. 155) göre medya okuryazarlı̆̆1, "medyanın kötü etkilerine ve yaşanan akımlara karşı korunmak için bir eğitim aracıdır". Taşkıran Öncel (2007, s. 7) medya okuryazarının "medyada kurgulanan mesajları ayırt edebilen aynı zamanda da algılayabilen, onunla ilgili yorumlarda bulunabilmek için ayrı bir beceri, altyapı bilgisi ve eğitsel yeterlilik gerektiren bir eğitim sürecinin sonucu olarak medya yetkini diye adlandırılabilecek kişiyi betimleyen bir terim" olarak kullanılabileceğini ifade etmiştir. Medya okuryazarlığı kavramı yerine genellikle medya eğitimi ifadesini kullanan UNESCO'nun, düzenlediği konferanslarda ve yayımladığı çalışmalarda bu kavram üzerinde çokça durduğu görülmektedir. UNESCO, medya okuryazarlığını 1979 Paris Birleşiminde şöyle tanımlamıştır: "Hem pratik ve teorik sanatlar olarak medyanın tüm seviyelerdeki (ilk, orta, lise, yetişkin eğitimi, yaşam boyu eğitim) ve tüm durumlardaki bütün çalışma, öğrenme ve öğretim biçimleri, tarihi, yaratıcılı̆̆ı, kullanımı ve değerlendirilmesi, hem de toplumda medyanın işgal ettiği yer, sosyal etkisi, medya iletişiminin, katılımının içinde saklı olan anlam, sebep oldukları algılama tarzı değişikliği, yaratıcı çalışma rolü ve medyaya ulaşma" (UNESCO, 1984'ten akt. Altun, 2010, s. 14). Yapılan tanımlamalardan medya okuryazarlığının okuma, konuşma, yazma, eleştirel yaklaşma, çözümleme ve değerlendirmeyi kapsayan bir beceri, algılama ve üretme yeteneği olduğu sonucu çıkarılabileceği düşünülmektedir.

Medya okuryazarlığı, medyayı doğru anlama, doğru yorumlama ve medyayı doğru kullanabilme becerilerinin dışında toplumsal düzenin sağlanması açısından da yararlanılabilecek 
bir alan olarak görülmektedir. "Medya okuryazarlığı; izleyicinin medyayı doğru okumasına katkı sağlamanın yanında, bireyin kendini özgürce ifade etmesi, toplumsal yaşama daha aktif ve yapıcı katılım, yerel, ulusal ve kamusal medyanın iyileştirilmesi ile ilgili çalışmaları desteklemek için bilinç oluşturma gibi konular da etki alanındadır" (Coşkunserçe, 2007, s. 55).

Televizyondaki reklamlardan gazetedeki yazılara, yiyecek ambalajlarındaki sloganlardan giydiğimiz kıyafetlerdeki yazılara kadar medyayla her daim iç içeyiz. Medyayla bu denli yüz yüze olmamızdan dolayı bireyin mesajlara ulaşma, onları çözümleme ve değerlendirme becerilerini geliştirmek, bireyi toplumda aktif kılmak adına toplum fertlerinin medya okuryazarlığı becerisini kazanmasını gerekli hâle getirmektedir. Medya okuryazarlığı, insanların içinde bulundukları dünyanın kodlarını anlamalarını, onlar hakkında aktif şekilde değerlendirme ve eleştiri yapmak suretiyle kişisel yargılar geliştirebilmelerini ve yeni mesajlar oluşturmalarını mümkün kılacak bir beceriye işaret etmektedir. Medya okuryazarlığı bireye medyayı ve medya iletilerini doğru okuması ve anlamlandırması hususunda katkı sağlar. Medyanın verdiği iletileri doğru bir şekilde anlamanın ve kullanmanın yolu ise iyi bir medya okuryazarlığı eğitimi almaktan geçmektedir. Medyayı eğitimin bir parçası olarak kullanma, sınıfta gazete ve derginin okunması, toplu halde TV izleme, okul gazetesi çıkarma, okul radyosundan yayın yapma 1970'li yıllarda ortaya çıkmıştır. 1980'li yılların sonlarına doğru medyada yaşanan küreselleşme ile birlikte vatandaşların medyanın olumsuz etkilerinden korunması gündeme gelmiş; uluslararası kurum ve kuruluşlarca çeşitli projelerde medya okuryazarlığı eğitiminin önemi tartışılmaya başlanmıştır. Yazılı, sesli ve görsel bütün kitle iletişim araçlarının sunduğu mesajlarla çevrili bir dünyada aktif bir vatandaş olmak için zengin bir iletişim becerisine gerek duyulduğu ileri sürülmüştür (Türkoğlu, 2004, s. 95).

Medya okuryazarlığ eğitimi her yaş grubundan bireyin dâhil edildiği, hayat boyu güncellenerek devam edecek bir eğitimdir. "Medya okuryazarlığı dersinde güncellemeler yapılarak dersin niteliğinin artması ve medya okuryazarlarının niteliğinin artması kamusal açıdan da önem taşımaktadır" (Asrak Hasdemir, 2012, s. 37).

\section{Türkiye'de medya okuryazarlığın gelişimi ve medya okuryazarlığı öğretim programları}

Türkiye'de medya okuryazarlığına dair gelişmelerin oldukça yakın bir tarihte başladığ söylenebilir. Medya okuryazarlığına yönelik ilginin ortaya çıkmasında ve bu alana yönelik çalışmaların başlatılmasında Radyo ve Televizyon Üst Kurulu (RTÜK) büyük bir etkiye sahiptir (Çakır, Koçer ve Aydın, 2012, s. 44). RTÜK resmî sitesinde medya okuryazarlığının gereklilik sebeplerini şu şekilde açıklamıştır:

"Çocukların fiziksel, bilişsel ve sosyal gelişimleri üzerinde medyanın olumlu ve olumsuz etkileri olduğu ileri sürülmektedir. Yapılan araştırmalar medyanın özellikle çocukların hayatlarında zaman ve mekân olarak yerinin artmakta olduğunu göstermektedir. Diğer yandan medya iletilerinin kendine has yapısının, dilinin ve uygulamalarının olduğu ve bunların sürekli değişmekte, gelişmekte olduğu da ortadadır. Bireylerin bu mecraları daha verimli kullanmaları ve bunu yaparken etkisinde kalınabilecek bazı riskler karşısında farkındalık geliştirebilmeleri için, medya iletileri ve yöntemleri konusunda bilgi sahibi olmaları gerekmektedir. Dolayısıyla bu durum, çocukların medya konusunda eğitim almalarının önemini ve verilecek eğitimin de olabildiğince güncellenmesi gerektiğini ortaya koymaktadır. Alandaki öncü ülkelerde sürdürülen bu çalışmalar, 'Medya Okuryazarlı̆̆ı' eğitimi olarak adlandırılmaktadır" (https://www.medyaokuryazarligi.gov.tr).

Toplumsal ve bireysel hayatta etkisi ve önemi giderek artan iletişimin toplum üzerindeki etkisine dair görüşlerin paylaşılıp tartışılması için geniş bir katılım sağlanması amacıyla RTÜK'ün organizasyonuyla, Basın-Yayın ve Enformasyon Genel Müdürlüğ̈̈ ve Türkiye Radyo Televizyon Kurumunun (TRT) da iş birliğiyle Ankara'da 20-21 Şubat 2003 tarihinde İletişim Şûrası düzenlenmiştir. RTÜK, şûra sonrasında medya okuryazarlığı dersinin müfredata eklenmesi konusunu gündemine almış, Millî Eğitim Bakanlığıyla iletişime geçilmesiyle birlikte 2004 yılında, okullarda medya okuryazarlı̆̆ 1 dersleri verilmesinin önemine vurgu yapılmıştır (Kazan ve Balkın, 2018, s. 250). 2005 yılında Marmara Üniversitesi İletişim Fakültesi tarafindan Türkiye'de ilk kez Uluslararası Medya Okuryazarlığı Konferansı düzenlenmiştir. Bu konferansta 
RTÜK, Medya okuryazarlığının neden gerekli olduğuna ilişkin resmî bir bildiri sunmuştur. Bu konferanstan sonra medya okuryazarlığı konusu her yönüyle tartışılmaya, medya okuryazarlı̆̆ıyla ilgili üniversitelerde dersler açılmaya, medya ve medya okuryazarlığıyla ilgili tezler ve çeviriler yaptırılmaya, telif kitaplar üretilmeye başlanmıştır (Erdem, 2018, s. 418). Kalkınma planları ve Millî Eğitim şûralarında tekrar tekrar öğretim programlarının, öğrencilerin bilgiye ulaşma yollarını öğrenmelerine, sorun çözme ve karar verme becerilerini geliştirmelerine imkân sağlayacak şekilde yeniden düzenlenmesine ihtiyaç olduğu dile getirilmiştir. Tüm bu ihtiyaçlar doğrultusunda RTÜK ile Millî Eğitim Bakanlığı Talim ve Terbiye Kurulu Başkanlığı ortak bir noktada birleşerek "Orta Öğretim Kurumlarına Medya Okuryazarlığı Dersi Konulmasına Dair İşbirliği Protokolü”nü imzalamışlardır. Medya okuryazarlığının eğitim-öğretim hayatına girişi, medya okuryazarlığıyla ilgili çalışmaları yürütmek üzere bir komisyonun oluşturulmasıyla başlamıştır. Talim ve Terbiye Kurulu Başkanlığı ile RTÜK uzmanları ve iletişim bilimleri akademisyenlerinden oluşan komisyon tarafından "Medya Okuryazarlığı Dersi Öğretim Programı ve Öğretmen Kılavuzu" hazırlanmıştır. 31 Ağustos 2006 tarihinde hayata geçirilen "İlköğretim Seçmeli Medya Okuryazarlığı Dersi Öğretim Programı", Millî Eğitim Bakanlığı tarafından belirlenen beş pilot ilde (Adana, Ankara, Erzurum, İstanbul, İzmir) seçmeli ders olarak okutulmaya başlanmış ve dersi sosyal bilgiler öğretmenlerinin vermesi kararlaştırılmıştır (www.medyaokuryazarligi.gov.tr). Seçmeli medya okuryazarlığı dersinin ilköğretim okullarının 7. sınıfında haftada bir ders saati olarak toplamda 36 saatlik bir sürede verilmesi hedeflenmiştir. Medya okuryazarlığı dersi, haftada 1 saat okutulacak seçmeli bir ders olduğundan dersin notla değerlendirilmemesine, karnede öğrencinin bu dersi aldığının belirtilmesine karar verilmiştir. Yine RTÜK tarafindan 2007 yılında İlköğretim Medya Okuryazarlığ 1 Öğretmen El Kitab1 hazırlanmıştır (Erdem, 2018, s. 418; Kazan ve Balkın, 2018, s. 251).

MEB'in 2007-2008 Öğretim Yılı'nda seçmeli ders olarak müfredata aldığı medya okuryazarlığı dersi kapsamında 25-28 Haziran tarihleri arasında 103 öğretmene medya okuryazarlığı eğitimiyle ilgili hizmet içi eğitim verilmiştir. RTÜK tarafından 2007-2008 Öğretim Yılı'nda öğrenci ve velileri bilinçlendirmek maksadıyla tanıtım filmi hazırlamıştır. Bu filmin amac1, olabildiğince çok öğrenci tarafından seçmeli medya okuryazarlığ 1 dersinin seçilmesini sağlamaktır (İnal, 2009, s. 164).

30 Haziran-01 Temmuz 2012 tarihlerinde, "Medya Okuryazarlığı Dersi Çalışma Grubu" ve "Yaşam Boyu Medya Okuryazarlığı Çalışma Grubu" olmak üzere iki grup hâlinde RTÜK, Aile ve Sosyal Politikalar Bakanlığı ile Millî Eğitim Bakanlığının ortak katkısıyla Ankara'da "Medya Okuryazarlığı Çalıştayı" düzenlenmiştir. Medya Okuryazarlığı Çalıştayı'nda alınan tavsiye kararları temel alınarak medya okuryazarlığ 1 dersinin güncellenmesi amacıyla RTÜK ve Millî Eğitim Bakanlığı Temel Eğitim Genel Müdürlüğü arasında 23 Mayıs 2013 tarihinde "İlköğretim Öğrencilerinde Medya Okuryazarlığı Bilincinin Geliştirilmesi ve Medya Okuryazarlığı Dersine Yönelik İşbirliği Protokolü” imzalanmıştır. Protokolün imzalanmasıyla birlikte yeni bir Medya Okuryazarlığı Dersi Öğretim Programı geliştirilmesi için Millî Eğitim Bakanlığı, Radyo ve Televizyon Üst Kurulu ve akademisyenlerden oluşan bir komisyon çalışmalarını başlatmıştır. Hazırlanan öğretim programı, Millı Eğitim Bakanlığı Talim ve Terbiye Kurulu Başkanlığı tarafından 27 Ocak 2014 tarihinde onaylanmıştır. Ayrıca "Medya Okuryazarlığı Dersi Öğretim Materyali” hazırlanması yönünde de karar alınmıştır. Komisyon tarafından hazırlanan Öğretim Materyali, 2014-2015 eğitim-öğretim yılında okutulmaya başlanmıştır (//www.medyaokuryazarligi.gov.tr). Ortaokul ve İmam Hatip Ortaokulu Medya Okuryazarlığı Dersi Öğretim Programı'na göre; derslerde ders kitabı kullanılmaması ve ilgili Genel Müdürlük tarafından öğretim materyali hazırlanması ifade edilmiştir. Programda, medya okuryazarlığına dair 21 kazanım için toplamda 72 saatlik bir ders süresi ayrılmıştır (MEB, 2013).

Yine Millî Eğitim Bakanlığı tarafindan "2016 Ortaokul ve İmam Hatip Ortaokulu Medya Okuryazarlığı Öğretim Materyali” ve 2018 yılında "2018 Medya Okuryazarlığı Dersi Öğretim Programı (Ortaokul ve İmam Hatip Ortaokulu 7 veya 8. Sınıflar)” uygulamaya konulmuştur. 2018 Medya Okuryazarlığı Dersi Öğretim Programı; "Bilgi, Beceri ve Duyuş" boyutlarıyla, bu boyutların ilişkilendirildiği "Medya Okuryazarlı̆̆ İlkeleri ve Medya Çeşitliliği" bağlamlarından oluşmaktadır. $\mathrm{Bu}$ doğrultuda öğretim programı; medya okuryazarlığı alan bilgisi, ilkeleri ve 
medya çeşitliliğini; öğrenmeyi öğrencinin yaşamı ile doğrudan ilişkili hale getirmek için beceri ve değer boyutlarıyla ilişkilendirerek ele alınmıștır (MEB, 2018). 2018 Medya Okuryazarlığı Dersi Öğretim Programı genel olarak değerlendirildiğinde programın genişletilmiş beceri alanları, kazanımlarla elde edilecek değerlerin açıkça belirtilmesi bakımından medya eğitimine fayda sağlayacağı düşünülmektedir.

\section{Araştırmanın amacı}

Yaşamın birçok alanında medyanın yeri her geçen gün artarak önem kazanmaktadır. Çağın bir gerekliliği olan medya, çocuğun ilk sosyalleşme sürecini yaşadığı aile ortamında, varlığını daha fazla hissettirmektedir. "Çocuğun aileyle başlayan sosyalleşme sürecinde yaşanan gelişmelerin ve paylaşımların, medya karşısında henüz yeni bilinçlenmekte olan ve zayıf konumda bulunan çocuk için önemi çok fazladır. Bu sebeple çocuğun sosyal kimliğini kazanma sürecinde medyanın işleyiş biçimi ya da kime ne sunduğu, nasıl sunduğu çocuk ile medya ilişkisinde önemli bir etkendir" (Çiftçi Yeşiltuna, 2015, s. 19).

İletişim çeşitleri ile pek çok kitleden oluşan toplum arasındaki ilişkinin gelişimi, tarihsel geçmişi ve bu alandaki tüm çalışmalar, işleyişini kısa sürede değiştirmenin mümkün olmadığı bu yapıyı anlamamızı ve gerekli çözümlemeyi yapmamızı mecburi kılmaktadır. Bundan dolayı olsa gerek Millî Eğitim Bakanlığı, medya okuryazarlığını 2007-2008 eğitim-öğretim yılında seçmeli ders olarak ortaokullarda uygulama kararı almıştır. Bu kararın uygulamaya konulmasıyla birlikte ortaya çıkan durumda yeniliğe ve gelişmeye ihtiyaç duyulmaktadır. Ortaya çıkan ihtiyaçları giderici eksikliklerin tespit edilmesi ve çalışmaların çağa uygun bir şekilde ilerlemesi önem taşımaktadır.

Medya okuryazarlığı ile ilgili Türkiye'de özellikle son yıllarda bilimsel çalışmaların $\operatorname{arttığ1~görülmektedir.~Medya~okuryazarlığı~konusuyla~ilgili~yapılan~çalışmalar~incelendiğinde;~}$ öğrencilerin medya okuryazarlığı düzeylerinin incelendiği, medya okuryazarlığına karşı öğretmen ve öğrenci tutumlarının tespitine dönük çalışmaların yapıldı̆̆ 1 , medya okuryazarlığ programlarının incelendiği araştırmalara rastlanmaktadır (Aktı, 2011; Bacaksız, 2010; Bakan, 2010; Barut, 2015; Bozkurt, 2012; Bütün, 2010; Cangin, 2014; Çinelioğlu, 2013; Görgülü Aydoğdu, 2015; Görmez, 2014; Işkın, 2015; İnan, 2013; Kaplan, 2017; Karataş, 2017; Keleş, 2013; Koçak, 2011; Kutlu, 2018; Najafl1, 2018; Naza, 2014; Oflaz, 2016; Okuroğlu, 2016; Özdemir, 2015; Sadru, 2009; Sayın, 2015; Semiz, 2013; Sivritepe, 2014; Şahin, 2012; Tan, 2015; Tatar, 2016; Ulusoy, 2018; Yıldırım, 2017). Bununla birlikte medya okuryazarlı̆̆ıyla ilgili çalışmaların bütün bu boyutlarını (program, öğrenci, öğretmen adayı, öğretmen) içine alan çalışmaların ise sınırlı olduğu tespit edilmiştir. Bu nedenlerden dolayı bu çalışmada ortaokul öğrencilerine, dersi veren öğretmenlere ve dersi vermesi öngörülen öğretmen adaylarına yönelik böyle bir çalışmanın yapılması gerekli görülmüş ve medya okuryazarlığı dersine dair olası sorunların kaynakları bir bütün olarak ele alınmaya çalışılmıştır.

Çocukların, televizyon ya da diğer kitle iletişim araçları karşısında etkiye en açık ve en hassas grubu oluşturduğu bir gerçektir. Çocuklar gerçek ile kurguyu ayırt edecek bir yaşta ve donanımda olamadıklarından dolayı, gördükleri her şeyi gerçeklik olarak algılayıp olabilirliğine inanmaktadırlar. Görsel, işitsel ve yazılı medya karşısında savunmasız bir alıcı durumunda bulunan çocukların ilköğretimden başlayarak medya iletişim araçları hakkında bilinçlendirilmeleri gerekmektedir. Çocuklar, medya okuryazarlığ dersi sayesinde medyanın, olayları nasıl ve neden belli yönleriyle yansıttığını anlayabilecek, medyaya ve medya iletilerine eleştirel bakabilen bireyler olarak yetiştirilecektir (Aytaş ve Kaplan, 2017, s. 306). Çocuklar bilinçlendikçe medyanın, onlar üzerindeki olumsuz etkileri de en aza inecektir. Çocuğun sahip olmasını istediğimiz bu becerilerin edinilmesinde medya okuryazarlığı eğitimi önemli bir yere sahiptir. Bundan dolayı medya okuryazarlığ adaylarının derse dair görüşlerinin yanı sıra ihtiyaçlarının da tespit edilmesi önem arz etmektedir. Ayrıca medya okuryazarlığı dersini alan öğrencilerin derse karşı olan tutumlarının ve beklentilerinin belirlenmesinin de gerekli olduğu düşünülmektedir. Bu araştırmayla; ortaokul öğrencilerinin derse karşı tutumları, Türkçe ve sosyal bilgiler öğretmenleri ile öğretmen adaylarının medya okuryazarlığına ilişkin görüşleri belirlenerek alanyazına katkı sağlanacağı 
düşünülmektedir. $\mathrm{Bu}$ hedefle araştırmanın temel amacı, medya okuryazarlığı dersine ilişkin öğrenci tutumlarını belirlemek ve medya okuryazarlığı dersine ilişkin öğretmen ile öğretmen adaylarının görüşlerini tespit etmektir. Bu temel amaç doğrultusunda çalışmada aşağıdaki alt amaçlara yanıt aranmıştır:

1. Medya okuryazarlığ dersini alan ve almayan öğrencilerin medyayı algılama biçimine ilişkin görüşleri arasında anlamlı bir farklılık var mıdır?

2. Medya okuryazarlığı dersinin işleniş biçimine ilişkin öğrenci tutumları nasıldır?

3. Medya okuryazarlığı dersinin algılanma biçimine ilişkin öğrenci tutumları nasıldır?

4. Medya okuryazarlı̆̆ 1 dersinin etkilerine ilişkin öğrenci tutumları nasıldır?

5. Medya okuryazarlığı dersini alan ve almayan öğrencilerin medya araçlarını tercihleri arasında anlamlı bir farklılık var mıdır?

6. Medya okuryazarlığı dersini veren öğretmenlerin bu derse ilişkin görüşleri nelerdir?

7. Türkçe ve sosyal bilgiler öğretmen adaylarının medya okuryazarlığına ilişkin görüşleri nelerdir?

\section{Yöntem}

Medya okuryazarlığı dersine ilişkin öğrenci tutumlarını belirlemeyi ve medya okuryazarlığ dersine ilişkin öğretmen ile öğretmen adaylarının görüşlerinin tespit edilmesini amaçlayan bu çalışma nicel ve nitel araştırma yöntemlerinin bir arada kullanıldığı karma model ile desenlenmiştir. Birbirini destekleyen nicel ve nitel yöntemlerin birlikte kullanılması, araştırma problemine ilişkin daha kapsamlı çözümlemelerin ve yorumlamaların yapılmasına olanak sağlamaktadır (Creswell ve Plano Clark, 2015). Araştırmanın nicel boyutunda tutum ölçeği, nitel boyutunda ise görüşme formu kullanılmıştır. Nicel araştırmada sayısallaştırma vardır. Nitelden fark1 da budur. Verileri sayısallaştırma nesnelliği sağlayacak bir yol olarak görülmektedir (Barışeri, 2013, s. 4). Nitel araştırma ise, gözlem, görüşme ve doküman analizi gibi nitel veri toplama yöntemlerinin kullanıldı̆̆ı, algıların ve olayların doğal ortamda gerçekçi ve bütüncül bir biçimde ortaya konmasına yönelik nitel bir sürecin izlendiği araştırma olarak ifade edilmektedir (Yıldırım ve Şimşek, 2013, s. 39).

Araştırmanın, bilimsel araştırma ve yayın etiğine uygunluğunun belgelenmesi amacıyla Giresun Üniversitesi Bilimsel Araştırma ve Yayın Etiği Kurulu'na başvurulmuştur. Yapılan başvuru, Kurul'un 21.04.2020 tarihli 2020-3 karar sayılı toplantısında değerlendirilerek araştırmanın etik ihlal içermediğine karar verilmiştir. Araştırma kapsamında görüşme yapılmadan önce öğretmen ve öğretmen adaylarına araştırmanın amacının ne olduğu ve yöneltilecek sorular hakkında bilgi verilmiştir. Görüşmelerin ses kayıt cihazı ile kaydedileceği bildirilerek kendilerinden gönüllü olur ve izin alınmıştır. Bu bilgiler ışığında, araştırmada bilimsel araştırma ve yayın etiğine uyulmuştur.

\section{Çalışma grubu}

Araştırmanın nicel verilerinin toplandığ çalışma grubunu, 2017-2018 eğitim-öğretim yılında Giresun ilinde seçmeli medya okuryazarlığ dersinin verildiği 5 ortaokulun medya okuryazarlığ dersini alan 153 sekizinci sınıf öğrencisi ile medya okuryazarlığı dersini almayan 103 yedinci sınıf öğrencisi oluşturmaktadır. Toplamda 256 öğrenci araştırmaya katılmıştır. Giresun ilindeki ortaokullarda medya okuryazarlığ dersi 2016-2017 eğitim-öğretim yılında 7. sınıflara verildiği için araştırmanın yapıldığ 1 2017-2018 yılından bir önceki yıl medya okuryazarlığ 1 dersini almış 8. sınıfa başlayan öğrenciler çalışmaya dâhil edilmiştir. Nitel verilerinin toplandığ 1 çalışma grubunu ise seçmeli medya okuryazarlığı dersinin verildiği okullarda görev yapan 5 sosyal bilgiler ile 1 Türkçe öğretmeni ve Giresun Üniversitesi Eğitim Fakültesindeki 15 Türkçe ile 15 sosyal bilgiler öğretmen adayı oluşturmaktadır. Araştırmanın nitel ve nicel çalışma grupları tesadüfi metotla evreni örnekleyecek şekilde belirlenmiştir.

\section{Veri toplama}

Araştırmanın nicel ve nitel verileri için farklı veri toplama teknikleri kullanılmıştır. Araştırmanın nicel bölümünde; seçmeli medya okuryazarlığı dersini alan ve almayan öğrencilerin medya 
okuryazarlığı dersine ilişkin tutumlarını ve tutumları arasında anlamsal ilişki olup olmadığını tespit etmek için "Medya Okuryazarlığı Tutum Ölçeği”"ne başvurulmuştur.

Medya Okuryazarlığı Tutum Ölçeği: Ölçek, 7 ve 8 . sınıf öğrencilerin medya okuryazarlığ 1 tutumlarını ölçmek amacıyla Elma ve diğerleri (2009) tarafından geliştirilmiştir. Ölçeğin kullanımı için gerekli izinler alınmıştır. Medya Okuryazarlık Tutum Ölçeği 2 bölüm, 4 alt boyut ve 31 maddeden oluşan 5'li likert tipi bir ölçüm aracıdır. Öğrencilerden ölçekteki her bir ifadeye "Kesinlikle Katılmiyorum", "Katılmiyorum", "Kararsızım", "Kat1lyorum", "Kesinlikle Katılıyorum" seçeneklerinden konuya ilişkin tutumlarını en iyi yansıtan seçeneği işaretlemeleri istenmiştir. Elde edilen veriler sayısal olarak kodlanarak bilgisayar ortamına aktartılmıştır. Araştırmanın nitel bölümünde; medya okuryazarlığıyla ilgili öğretmen ve öğretmen adaylarının görüş ve bilgilerinin tespiti için "Kişisel Bilgi Formu" ve "Görüşme Formu” na başvurulmuştur.

Kişisel bilgi formu: Araştırmacı tarafından ilgili kaynaklar taranarak hazırlanan kişisel bilgi formuyla çalışma grubunda yer alan öğrencilerin demografik özelliklerine ve medya araçlarını kullanma alışkanlıklarına ilişkin bilgiler toplanmıştır.

Öğretmen görüşme formu: Çalışmanın amaç ve alt amaçlarına uygun olarak ilgili kaynaklar taranarak 26 soruluk yarı yapılandırılmış görüşme formu geliştirilmiştir. Yarı yapılandırılmış görüşme tekniği, sahip olduğu belirli düzeydeki standartlık ve aynı zamanda sağladığı esneklik nedeniyle eğitim araştırmalarında sıklıkla kullanılan bir tekniktir (Türnüklü, 2000, s. 547). Görüşme formu, soruların açık uçlu olmasına, çok boyutlu olmamasına ve katılımcılar tarafından kolay anlaşı1ır olmasına dikkat edilerek hazırlanmıştır. Çalışmanın amaç ve alt amaçlarına uygun olarak ilgili literatür taranarak oluşturulan taslak yarı yapılandırılmış Öğretmen Görüşme Formu'nun "kapsam geçerliği" ile ilgili olarak uzman görüşüne başvurulmuştur. Araştırmac1 tarafından oluşturulan 26 soruluk taslak form, 3'ü Türkçe eğitimi, 1'i eğitim programları ve öğretimi, 1'i de ölçme-değerlendirme alanında uzman olmak üzere 5 öğretim üyesine sunulmuştur. Bu bağlamda uzmanlara formda yer alan her bir soruya ilişkin olarak "uygun", "uygun değil" ve "geliştirilmesi gerekir" seçeneklerini göz önünde bulundurarak değerlendirmeleri istenmiştir. Uzmanların görüşleri doğrultusunda gerekli düzeltmeler yapılarak görüşme formuna son hâli verilmiştir. Son hâli verilen öğretmen görüşme formunda 8 soru yer almıştır. Öğretmenlerle görüşmeler yüz yüze yapılmış ve her bir görüşme yaklaşık 30 dakika sürmüştür. Yapılan görüşmeler ses kayıt cihazı ile kaydedilmiştir. Görüşme yapılmadan önce öğretmenlere araştırmanın amacının ne olduğu ve yöneltilecek sorular hakkında bilgi verilmiştir. Görüşmelerin ses kayıt cihazı ile kaydedileceği bildirilerek kendilerinden izin alınmıştır. Görüşme sonrasında ses kayıtları çözümlenerek yazılı hâle getirilmiş ve yazılı metinler katılımcı teyidi almak için kendilerine gönderilmiştir.

Öğretmen adayı görüşme formu: Öğretmen adaylarının görüşlerini almak amacıyla çalışmanın amaç ve alt amaçlarına uygun olarak ilgili literatür taranarak 8 soruluk yarı yapılandırılmış görüşme formu geliştirilmiştir. Görüşme formu, soruların açık uçlu olmasına, çok boyutlu olmamasına ve katılımcılar tarafından kolay anlaşılır olmasına dikkat edilerek hazırlanmıştır. Çalışmanın amaç ve alt amaçlarına uygun olarak ilgili literatür taranarak oluşturulan taslak Öğretmen Adayı Görüşme Formu "kapsam geçerliği” için uzman görüşüne başvurulmuştur. Araştırmacı tarafından oluşturulan taslak form, 3'ü Türkçe eğitimi, 1'i eğitim programları ve öğretimi, 1'i de ölçme-değerlendirme alanında uzman olmak üzere 5 öğretim üyesine sunulmuştur. Bu bağlamda uzmanlara formda yer alan her bir soruya ilişkin olarak "uygun", "uygun değil" ve "geliştirilmesi gerekir" seçeneklerini göz önünde bulundurarak değerlendirmeleri istenmiştir. Uzmanların görüşleri doğrultusunda gerekli düzeltmeler yapılarak görüşme formuna son hâli verilmiştir. Öğretmen adayı görüşme formunun son halinde 5 soru yer almıştır. Öğretmen adaylarıyla görüşmeler yüz yüze yapılmış ve her bir görüşme yaklaşık 10 dakika sürmüştür. Yapılan görüşmeler ses kayıt cihazı ile kayıt altına alınmıştır. Görüşme yapılmadan önce öğretmen adaylarına araştırmanın amacının ne olduğu ve yöneltilecek sorular 
hakkında bilgi verilmiştir. Görüşmelerin ses kayıt cihazı ile kaydedileceği bildirilerek kendilerinden izin alınmıştır. Görüşme sonrasında ses kayıtları çözümlenerek yazılı hale getirilmiş ve yazılı metinler katılımcı teyidi almak için kendilerine gönderilmiştir.

\section{Verilerin analizi}

Ortaokul öğrencilerinin medya okuryazarlı̆̆ına dair düzeylerini belirlemeyi amaçlayan araştırmada toplanan nicel verilerin çözümlenmesinde SPSS 16.0 programı kullanılmıştır. Verilerin medya okuryazarlığı dersini alan ve almayan öğrenciler değişkeni açısından karşılaştırılması amacıyla frekans, aritmetik ortalama teknikleri kullanılmıştır. Medya okuryazarlığı dersini alan ve almayan öğrencilerin medyayı algılama biçimine ilişkin görüşlerine dair ortalamaların çözümlenmesinde aritmetik ortalama, medya okuryazarlığ dersini alan ve almayan öğrenci değişkeninin etkisini test etmek için ise $t$ testi kullanılmıştır. Elde edilen verilerin analizinde anlamlılık düzeyi $0.05(\mathrm{p}<0.05)$ olarak uygulanmıştır. Bulgular, tablolar hâlinde sunulmuş ve yorumlanmıştır.

Öğrenci tutumlarına dair verilerin toplanmasında kullanılan ölçekte yer alan aralık değerlerini derecelendirmek için aralık hesaplama yoluna gidilmiştir. Bundan dolayı ölçekte yer alan aralık değerleri $n=5$ olmak üzere, $n=(n-1) / n$ formülü ile $(5-1) / 5=0.80$ aralık genişliği formülü uygulanmış ve Tablo 1'deki aralıklar ortaya çıkmıştır.

Tablo 1.

Ölçek Puan Aralık Tablosu

\begin{tabular}{lcc}
\hline Seçenekler & Puan & Puan Aralı̆̆ \\
\hline Kesinlikle Katılmiyorum & 1 & $1,00-1,80$ \\
\hline Katılmiyorum & 2 & $1,81-2,60$ \\
\hline Kararsizım & 3 & $2,61-3,40$ \\
\hline Katıliyorum & 4 & $3,41-4,20$ \\
\hline Kesinlikle Katıliyorum & 5 & $4,21-5,00$ \\
\hline
\end{tabular}

Nitel verilerin analizinde ise görüşmeler yoluyla toplanan veriler içerik analizi ile çözümlenmiştir. İçerik analizi ile temelde birbirine benzeyen veriler belirli kavramlar ve temalar çerçevesinde bir araya getirerek anlaşılır bir biçimde düzenlenmiş ve yorumlanmıştır. Verilerin analizinde; verilerin kodlanması, temaların bulunması, kodların ve temaların düzenlenmesi, bulguların tanımlanması ve yorumlanması aşamaları izlenmiştir (Yıldırım ve Şimşek, 2013, s. 259-260). Araştırmada elde edilen sonuçların aktarılabilirliğinin sağlanabilmesi için veriler ayrıntılı bir biçimde betimlenmiş ve yer yer doğrudan alıntılar ile desteklenmiştir. Yapılan doğrudan alıntılarda katılımcıların gerçek isimleri gizli tutulmuş, doğrudan alıntılar Ö1, Ö2, ... Ö6; TÖA1, TÖA2, ... TÖA15; SBÖA1, SBÖA2, ... SBÖA15 biçiminde ifade edilmiştir. Öğretmen ve öğretmen adaylarının görüşlerinden birebir alıntı yapılarak "geçerlik" sağlanmıştır. Çünkü görüşülen bireylerden doğrudan alıntılara yer vermek ve bunlardan yola çıkarak sonuçları açıklamak, "geçerlik" için önemli olmaktadır (Yıldırım ve Şimşek, 2013). Nicel ve nitel verilerin analizinden elde edilen sonuçlar birlikte değerlendirilmiş ve yorumlanmıştır.

\section{Bulgular}

Medya okuryazarlığı dersini alan ve almayan öğrencilerin medyayı algılama biçimine ilişkin bulgular

Araştırmaya katılan öğrencilerin medyanın algılanma biçimi boyutunda yer alan ifadelerine iliş̧in $t$ testi sonuçları Tablo 2'de verilmiştir.

Tablo 2.

Medyanın Algılanma Biçimi Boyutuna İlişkin T Testi Sonuçları 


\begin{tabular}{lcccccccc}
\hline \multirow{2}{*}{ Boyutlar } & \multicolumn{2}{c}{$\begin{array}{c}\text { Dersi alan } \\
(\mathrm{n}=153)\end{array}$} & \multicolumn{2}{c}{$\begin{array}{c}\text { Dersi almayan } \\
(\mathrm{n}=103)\end{array}$} & $\mathrm{t}$ & sd & P \\
\cline { 2 - 5 } & $\overline{\boldsymbol{X}}$ & SS & $\overline{\boldsymbol{X}}$ & SS & & & \\
\hline $\begin{array}{l}\text { Medyanin algilanma } \\
\text { biçimi }\end{array}$ & 3,35 & 0,34 & 3,2 & 0,35 & & 1,86 & 254 & 0,065 \\
\hline
\end{tabular}
$(\mathrm{P}<0.05)$

Tablo 2'ye göre, medyanın algılanma biçimi boyutuna yönelik medya okuryazarlığı dersini alan ve almayan öğrencilerin tutumları arasında anlamlı bir fark tespit edilmemiştir $(\mathrm{P}<0.05)$.

\section{Medya okuryazarlığı dersinin işleniş biçimine iliş̧kin bulgular}

Araştırmaya katılan öğrencilerin medya okuryazarlı̆̆ dersinin işleniş yöntemi boyutunda yer alan ifadelerine ilişkin ortalamalar Tablo 3 'te verilmiştir.

Tablo 3.

Medya Okuryazarlığı Dersinin İşleniş Yöntemi Boyutuna İlişkin Medya Okuryazarlığı Dersini Alan Öğrencilerin Madde Ortalama Puanları

\begin{tabular}{lccc}
\hline Maddeler & $\mathrm{N}$ & $\overline{\mathrm{X}}$ & $\mathrm{SS}$ \\
\hline Bu derste kullanılan araç-gereci yeterli buluyorum. & 153 & 3,65 & 1,19 \\
\hline Medya ile ilgili sınıf içi tartışmaları yeterli buluyorum. & 153 & 3,42 & 1,17 \\
\hline Medyaya ilişkin sınıf içinde yapılan etkinlikleri yeterli buluyorum. & 153 & 3,52 & 1,18 \\
\hline Bu derste kullanılan öğretim yöntemlerini yeterli buluyorum. & 153 & 3,75 & 1,22 \\
\hline Öğretmenimizin dersi işleme biçimini beğeniyorum. & 153 & 4,13 & 1,13 \\
\hline
\end{tabular}

Tablo 3 incelendiğinde, medya okuryazarlı̆̆ dersini alan öğrencilerin medya okuryazarlığı dersinin işleniş yöntemi boyutuna ilişkin toplamda en fazla katıldıkları ifadenin "Öğretmenimizin dersi işleme biçimini beğeniyorum" ( $(\bar{X}=4,13)$, en az katıldıkları ifadenin ise "Medya ile ilgili sınıf içi tartışmaları yeterli buluyorum" $(\bar{X}=3,42)$ olmuştur. Medya okuryazarlığı dersinin işleniş yöntemi boyutuna ilişkin madde ortalama puanları incelendiğinde; bu dersi alan öğrencilerin öğretmenin dersi işleme biçimini beğendiği, derste kullanılan araçgereci, derste kullanılan öğretim yöntemlerini ve sınıf içi etkinlikleri yeterli bulduğu görülürken sınıf içi tartışmaları yeterli bulmadığı görülmektedir.

\section{Medya okuryazarlı̆̆ dersinin algılanma biçimine iliş̧kin bulgular}

Araştırmaya katılan öğrencilerin medya okuryazarlığı dersinin algılanma biçimi boyutunda yer alan ifadelerine ilişkin ortalamalar Tablo 4'te verilmiştir.

Tablo 4.

Medya Okuryazarlığı Dersinin Algılanma Biçimi Boyutuna İlişkin Madde Ortalama Puanları

\begin{tabular}{lccc}
\hline Maddeler & $\mathrm{N}$ & $\overline{\mathrm{X}}$ & $\mathrm{SS}$ \\
\hline Bu dersi çok sıkıcı buluyorum. & 153 & 2,29 & 1,27 \\
\hline Bu dersin zorunlu olması gerektiğini düşünüyorum. & 153 & 3,18 & 1,3 \\
\hline $\begin{array}{l}\text { Bu dersin en ilgi çekici özelliğinin, çok farklı etkinliklerle işlenmesi olduğunu } \\
\text { düşüyorum. }\end{array}$ & 153 & 3,67 & 1,15 \\
\hline Bu dersin her kademede verilmesi gerektiğini düşünüyorum. & 153 & 3,07 & 1,33 \\
\hline Bu dersi almayan arkadaşlarıma, bu dersi seçmelerini tavsiye ediyorum. & 153 & 3,27 & 1,21 \\
\hline Bu dersin zevkli ve eğlenceli olduğunu düşünüyorum. & 153 & 3,25 & 1,22 \\
\hline
\end{tabular}




\begin{tabular}{llrrr}
\hline $\begin{array}{l}\text { Anne-babaların da medya-okuryazarlığı } \\
\text { düşünüyorum. }\end{array}$ & konusunda eğitilmesi & gerektiğini & & \\
\hline Bu dersin gerekli olduğunu düşünüyorum. & 153 & 3,89 & 1,24 \\
\hline Bu dersin yararlı olduğunu düşünüyorum. & 153 & 3,54 & 1,03 \\
\hline
\end{tabular}

Tablo 4 incelendiğinde medya okuryazarlı̆̆ 1 dersinin algılanma biçimi boyutuna ilişkin öğrencilerin toplamda en fazla katıldıkları ifadenin "Anne-babaların da medya-okuryazarlığ konusunda eğitilmesi gerektiğini düşünüyorum" $(\bar{X}=3,89)$, En az katıldıkları ifadenin ise "Bu dersi çok sıkıcı buluyorum" $(\bar{X}=2,29)$ olduğu belirlenmiştir. Medya okuryazarlığı dersinin algılanma biçimi boyutuna ilişkin madde ortalama puanları incelendiğinde; medya okuryazarlığı dersini alan öğrencilerin anne ve babaların medya okuryazarlığı konusunda eğitilmeleri gerektiğini düşündükleri görülmüştür. Bu dersin gerekli ve yararlı olduğunu düşünürken dersin zorunlu olmaması gerektiğini düşünüp dersi almayanlara bu dersi tavsiye etmedikleri anlaşılmıştır.Dersin en ilgi çekici özelliğinin çok farklı etkinliklerle işlenmesi olduğu düşünülürken bu dersi zevkli ve eğlenceli bulmadıkları da tespit edilmiştir.

\section{Medya okuryazarlı̆ğ dersinin etkilerine ilişkin bulgular}

Araştırmaya katılan öğrencilerin medya okuryazarlığ 1 dersinin etkileri boyutunda yer alan ifadelerine ilişkin ortalamalar Tablo 5'te verilmiştir.

Tablo 5.

Medya Okuryazarlığı Dersinin Etkileri Boyutuna İlişkin Medya Okuryazarlığı Dersini Alanların Madde Ortalama Puanları

\begin{tabular}{|c|c|c|c|}
\hline Maddeler & $\mathrm{N}$ & $\overline{\mathrm{X}}$ & SS \\
\hline $\begin{array}{l}\text { u dersi aldığımdan beri, ailemin televizyon izleme alışkanlığında değişme } \\
\text { duğunu gözlüyorum. }\end{array}$ & 153 & 2,5 & 1,24 \\
\hline $\begin{array}{l}\text { dersten edindiğim bilgileri, bu dersi almayan arkadaşlarımla da } \\
\text { alaşıorum. }\end{array}$ & 153 & 2,94 & 1,24 \\
\hline Medya Okuryazarlığı dersinde öğrendiklerimi ailemle de paylaşıyorum. & 153 & 2,76 & 1,25 \\
\hline Bu dersi aldıktan sonra, TV izleme alıșkanlığımın değiștiğini düşünüyorum. & 153 & 2,83 & 1,28 \\
\hline Medya Okuryazarlığı dersinin olaylara bakışımı değiştirdiğini düşünüyorum. & 153 & 3,1 & 1,14 \\
\hline $\begin{array}{l}\text { Bu dersten edindiğim bilgilerin tüketim alışkanlığımda daha seçici } \\
\text { davranmama yol açtığını düşünüyorum. }\end{array}$ & 153 & 2,71 & 1,26 \\
\hline $\begin{array}{l}\text { u dersi aldığımdan beri, gözlem yeteneğimin daha da geliştiğini fark } \\
\text { liyorum. }\end{array}$ & 153 & 3,14 & 1,2 \\
\hline $\begin{array}{l}\text { Bu dersi aldığımdan beri, TV'deki programların seçiminde daha seçici } \\
\text { davranıyorum. }\end{array}$ & 153 & 3,04 & 1,16 \\
\hline $\begin{array}{l}\text { u dersi aldığımdan beri, medya araçlarını (TV, radyo, gazete, internet) } \\
\text { ğişik bir gözle inceliyorum. }\end{array}$ & 153 & 3,2 & 1,07 \\
\hline $\begin{array}{l}\text { I dersi aldığımdan beri, medyada verilen mesajları daha eleştirel bir gözle } \\
\text { celiyorum. }\end{array}$ & 153 & 3,18 & 1,13 \\
\hline $\begin{array}{l}\text { dersten edindiğim bilgiler sayesinde daha } \mathrm{i} \\
\text { duğumu düşünüyorum. }\end{array}$ & & 3 & 1, \\
\hline
\end{tabular}

Tablo 5 incelendiğinde medya okuryazarlığı dersinin etkileri boyutuna ilişkin öğrencilerin toplamda en fazla katıldıkları ifadenin " $\mathrm{Bu}$ dersten edindiğim bilgiler sayesinde daha iyi bir medya okuryazarı olduğumu düşünüyorum" ( $\bar{X}=3,37)$, en az katıldıkları ifadenin ise "Bu dersi aldığımdan beri, ailemin televizyon izleme alışkanlığında değişme olduğunu gözlüyorum $(\bar{X}=2,5)$, olduğu belirlenmiştir. Medya okuryazarlığı dersinin algılanma biçimi boyutuna ilişkin madde ortalama puanları incelendiğinde; dersi alan öğrencilerin medya okuryazarllğ sayesinde daha iyi bir medya okuryazarı olduklarını, eleştirel ve seçici olduklarını, gözlem 
yeteneklerinin arttığını düşünürken öğrencilerin dersi aldıktan sonra televizyon izleme ve tüketim alışkanlıklarında herhangi bir değişim olmadığını düşündükleri, aileleriyle ve arkadaşlarıyla medya okuryazarlığı dersinde edindikleri bilgileri paylaşmaktan kaçındıkları görülmektedir.

\section{Medya okuryazarlığı dersini alan ve almayan öğrencilerin medya araç tercihlerine ilişkin} bulgular

Araştırmaya katılan öğrencilerin medya araçlarını tercihlerine ilişkin ilişkin $t$ testi sonuçları Tablo 6'da verilmiştir.

Tablo 6.

Medya Okuryazarlığı Dersini Alan ve Almayan Öğrencilerin Medya Araçlarını Tercih Sırasına İlişkin T Testi Sonuçları

\begin{tabular}{|c|c|c|c|c|c|c|c|}
\hline Medya Araçları & Grup & $\mathrm{N}$ & $\bar{X}$ & SS & $\mathrm{t}$ & $\mathrm{Sd}$ & $\mathrm{P}$ \\
\hline \multirow{2}{*}{ Televizyon } & 8. Sinif & 153 & 4,046 & 0,71 & \multirow{2}{*}{$-0,03$} & \multirow{10}{*}{254} & \multirow{2}{*}{0,976} \\
\hline & 7. Sinif & 103 & 4,049 & 0,784 & & & \\
\hline \multirow{2}{*}{ İnternet } & 8. Sinif & 153 & 4,745 & 0,674 & \multirow{2}{*}{2,45} & & \multirow{2}{*}{0,015} \\
\hline & 7. Sinif & 103 & 4,495 & 0,957 & & & \\
\hline \multirow{2}{*}{ Dergi } & 8. Sinif & 153 & 2,261 & 0,992 & \multirow{2}{*}{$-2,945$} & & \multirow{2}{*}{$0,004 *$} \\
\hline & 7. Sinif & 103 & 2,651 & 1,1 & & & \\
\hline \multirow{2}{*}{ Gazete } & 8. Sinif & 153 & 2,092 & 0,846 & \multirow{2}{*}{$-0,14$} & & \multirow{2}{*}{0,889} \\
\hline & 7. Sinif & 103 & 2,107 & 0,874 & & & \\
\hline \multirow{2}{*}{ Radyo } & 8. Sinif & 153 & 1,366 & 0,841 & \multirow{2}{*}{0,538} & & \multirow{2}{*}{0,591} \\
\hline & 7. Sinif & 103 & 1,311 & 0,755 & & & \\
\hline
\end{tabular}

$(\overline{\mathrm{P}<0.05)}$

Tablo 6'ya göre, medya okuryazarlı̆̆ dersini alan ve almayan öğrencilerin medya araçlarını tercih sıraları aynı olup sırasıyla internet, televizyon, dergi, gazete ve radyodur. İnternet tercihinde dersi alanlar, dergi tercihinde ise dersi almayanlar lehine anlamlı fark tespit edilmiştir $(\mathrm{P}<0.05)$.

Medya okuryazarlığı dersini veren öğretmenlerin bu derse ilişkin görüşlerine dair bulgular Medya okuryazarlığı dersini veren ögretmenlere bu dersin amaçları ve içeriğgi hakkındaki görüşleri sorulmuştur. Görüş bildiren öğretmenlerin 5'i medya okuryazarllğg 1 dersinin amaç ve içeriğinin öğrencileri iyi bir medya okuryazarı olacak şekilde yetiştirmeye yönelik hedeflerden oluştuğunu ifade etmiştir. Aşağıda bu görüşlerden biri aktarılmıştır:

"Medya okuryazarlı̆̆ dersinin temel amact ögrencilerin iyi bir medya izleyicisi ve okuryazarı olmasıdır. Medyanın bireye ulaştırdı̆̆ bilgileri okurun ya da dinleyicinin kendi beyin süzgecinden geçirmesi gerektiğini, bilgileri eleştirmesi gerektiğini öğreten bir derstir. İçeriğinde ise medya araçlarını tanımak, iletişimi sağlamak, medya da edilgen değil de etkin hale gelmeyi amaçlayan konular yer almaktadır (Ö5)."

Medya okuryazarllğı dersi veren öğretmenlere budersi gerekli görüp görmedikleri sorulmuştur. Ortaokullarda seçmeli olarak medya okuryazarlığı dersine giren ve görüş bildiren 6 öğretmenin tamamı budersi gerekli görmektedir. Görüş bildiren 6 öğretmenden 1'i seçmeli medya okuryazarllğı dersinin kendi okulunda ve diğer okullarda gerektiği gibi işlenmediğini düşünse de öğrencilerin medyanın zararlı etkilerinden korunabilmeleri için medya okuryazarlığ 1 dersini gerekli gördügünü söylemiştir.

"Kesinlikle her ögrrencinin alması gereken bir derstir (Ö3)." 
"Okulumuzda ve diğer okullarda her ne kadar gerektiği gibi işlenemese de medya okuryazarlı̆̆ı dersini gerekli görüyorum (Ö4)."

Medya okuryazarlı̆̆ dersini veren ve bu dersi ortaokullar için gerekli gören 5 öğretmen teknoloji çağında olunması, kalitesiz TV programlarının yayınlanması gibi durumlardan kaynaklı olumsuz etkilerden öğrencilerin kendilerini koruyabilmeleri ve seçici davranabilmeleri için medya okuryazarlığı dersini gerekli gördüklerini söylemiştir.

“Öğrencilerin oyun hayatını dahi olumsuz yönde etkileyen medyanın zararl yönlerinden korunmaları için medya okuryazarlı̆̆ dersiyle ögrenciler bilinçlendirilmeli (Ö4)."

"Sorgulamadan kabullendiğimiz bilgiler bizi yanlışa götürüyor. Yanlışa düşmemek için medya okuryazarlığıyla ilgili bilgiye sahip olunmalı (Ö6)."

Medya okuryazarlı̆̆ 1 dersi veren öğretmenlere bu derse girmeden önce herhangi bir ön hazırlık yapıp yapmadıkları, dersin öğreticisi olarak hangi kaynaklardan yararlandıkları sorulmuştur. Öğretmenlerin görüşleri Tablo 7'de sunulmuştur.

Tablo 7.

Medya Okuryazarlığı Dersi Veren Öğretmenlerin Ders Öncesi Ne Tür Hazırlıklar Yaptıklarına ve Hangi Kaynaklardan Yararlandıklarına İlişkin Görüşler

\begin{tabular}{lll}
\hline & & $\mathrm{f}$ \\
\hline Hazırlık yapmiyorum & Görüşler & Ö \\
\hline Hazırl1k yapiyorum & 4 \\
\hline Toplam & 2 \\
\hline
\end{tabular}

Ö: Öğretmenler

Tablo 7'de görüldüğü gibi 6 öğretmenin 4'ü herhangi bir ön hazırlık yapmadığını söylerken 2'si medya okuryazarlığı dersi için gereken hazırlı̆̆ yaptığını söylemiştir. Herhangi bir ön hazırlık yapmadığını söyleyen 3 öğretmenin 2'si medya okuryazarlığ 1 dersinin başka derslerin tamamlayıcısı olarak görüldüğünü ve o ders saatlerinde branş dersleri işlendiği için medya okuryazarlı̆̆ 1 dersine hazırlık yapmadıklarını dile getirmiştir.

"Herhangi bir ön hazırlık yapmıyorum. Derse girmeden önce hangi kazanımı vereceğimize bakiyorum (Ö1)."

"Medya okuryazarlığı başka bir dersin tamamlayıcısı olarak görüldüğü için herhangi bir hazırlı yapmıyorum bu ders için. İnkllâp Tarihi dersinin içerisinde medya okuryazarlığıyla ilgili temel kavramları vermeye çalışlyorum (Ö4)."

Medya okuryazarlığı dersi veren öğretmenlere söz konusu ders için yazılı basından düzenli bir biçimde takip ettikleri ve ortaokul öğrencileri ile bu dersi veren öğretmenlere önerebilecekleri gazete, dergi vb. yayınlar olup olmadığı sorulmuştur. Öğretmenlerin görüşleri Tablo 8'de sunulmuştur.

Tablo 8.

Medya Okuryazarlı̆̆ Dersi Veren Öğretmenlerin Dersle İlgili Öneride Bulunabilecekleri Kaynaklara İlişkin Görüşler

\begin{tabular}{ll}
\hline & $\mathrm{f}$ \\
\hline Görüşler & Ö \\
\hline
\end{tabular}




\begin{tabular}{ll}
\hline Tavsiye yok & 4 \\
\hline Ulusal yayınlar ve MEB'in tavsiye ettiği haber siteleri & 2 \\
\hline Toplam & 6 \\
\hline
\end{tabular}

Ö: Öğretmenler

Tablo 8'de görüldüğü gibi görüş bildiren 6 öğretmenin 4'ü takip ettikleri bir yayın olmadığını söylerken 2 öğretmen, öğrencilere bilgi edinmek için ulaşabildikleri bütün ulusal gazeteleri, MEB'in tavsiye ettiği haber sitelerini ve tek bir yayına bağlı kalmamalarını tavsiye etmiştir. Aşağıda katılımcıların bu ifadelerinden bir kısmına yer verilmiştir:

"Bu dersle ilgili herhangi bir kaynağımı yok. Konularla ilgili dokümanları internetten indirip derslerde kullanıyoruz. Ögretmenlere ve ögrencilere önerebileceğim tek bir yayın ya da gazete yok. Onlara tavsiyem bir bilgiye pek çok yayın ve gazeteden ulaşmaya çalışsınlar tek bir yayına bă̆lı kalmasınlar (Ö2)."

"Bulabildiğimiz ulusal bütün gazeteleri tavsiye ediyoruz. Bilim Çocuk dergisini çok fazla kullanıyoruz. Milli Eğitim'in tavsiye ettiği haber sitelerini kullanıyoruz ve ögrencilere tavsiye ediyoruz (Ö6)."

Medya okuryazarlığı dersi veren öğretmenlere yazılı ve görsel medyanın öğrencileri olumlu ve olumsuz yönleriyle nasıl etkilediğini sorulmuştur. Öğretmenlerin görüşleri Tablo 9' da sunulmuştur.

Tablo 9.

Medya Okuryazarlığı Dersi Veren Öğretmenlere Göre Medyanın Öğrenciler Üzerindeki Etkilerine İlişkin Görüşleri

\begin{tabular}{|c|c|}
\hline & $\mathrm{f}$ \\
\hline Görüşler & $\ddot{\mathrm{O}}$ \\
\hline Olumsuz etkilemekte & 3 \\
\hline Olumlu etkilemekte & 1 \\
\hline Olumlu ve olumsuz etkilemekte & 1 \\
\hline Etki gözlemlenemiyor & 1 \\
\hline Toplam & 6 \\
\hline
\end{tabular}

Ö: Öğretmenler

Tablo 9'da görüldüğü gibi görüș bildiren 6 öğretmenin 3'ü medyanın taraf olması, belli bir görüşü dayatmaya çalışması, öğrencileri şiddete yöneltmesi ve ahlaki deformasyona neden olması gibi nedenlerden dolayı öğrencileri olumsuz yönde etkilediğini ifade etmiştir. Görüşüne başvurulan 6 öğretmenin 1'i öğrencilerle yalnızca ders saati süresince birlikte olmaları gerekçesiyle yazılı ve görsel medyanın öğrenciler üzerinde nasıl bir etkiye sahip olduğunu gözlemleyemediklerini ifade ederken öğretmenlerden 1'i yazılı ve görsel medyanın ögrencileri hem olumlu hem de olumsuz yönde etkilediğini, 1'i de sadece olumlu yönde etkilediğini dile getirmiştir.

"Ancak medyanın ögrenciler üzerindeki olumlu ve olumsuz yanlarını gözlemleme imkânım yok. Öğrenciler medyanın olumlu ve olumsuz yanlarını ifade edebiliyorlar, görebiliyorlar fakat bu zarar ve faydaları ne kadar davranışlarına yansitabiliyorlar onu gözlemleme imkânımız olmuyor. Bunun nedeni de ben onlarla sadece ders içerisinde birlikteyim. Ders dişındaki zamanlarda öğrencilerin ne kadar süre medyanın etkisi altında kaldıklarını gözlemleyemiyorum (Ö1).", 
"Medyayı şu anda hayatın ortasında olarak görüyorum. Medya insanları nasıl yönlendirmesi gerektiğini bilen hem tehlikeli hem de çok faydalı bir araç, bu nedenle ögrenciler üzerinde olumlu ve olumsuz yanların birlikte görebiliyoruz (Ö6)."

Medya okuryazarlı̆̆ dersi veren öğretmenlere bu ders ile ilgili herhangi bir eğitim alıp almadıkları, aldılar ise bu eğitimi nasıl değerlendirdikleri, bu dersi verecek olan öğretmenlerin alması gereken eğitim hakkındaki önerileri sorulmuştur. Öğretmenlerin görüşleri Tablo 10 ve Tablo 11'de sunulmuştur.

Tablo 10.

Medya Okuryazarlığı Dersi Veren Öğretmenlerin Medya Okuryazarlı̆̆ı Dersiyle İlgili Eğitimlerine İlişkin Görüşler

\begin{tabular}{|c|c|}
\hline & $\mathrm{f}$ \\
\hline Görüşler & Ö \\
\hline$\overline{\text { Eğitim almadım }}$ & 5 \\
\hline Seminere katıldım & 1 \\
\hline Toplam & 6 \\
\hline
\end{tabular}

Ö: Öğretmenler

Tablo 10'da görüldüğü gibi 6 öğretmenin 5'i medya okuryazarlığına ilişkin eğitim almadığını söylerken, 1 öğretmen medya okuryazarlığıyla ilgili birkaç günlük seminere katıldığını ve bu semineri faydalı bulmadığını söylemiştir.

"Bu konuyla ilgili bir eğitim almadım, birkaç günlük seminere gittim ve çok da faydalı olduğunu düşünmüyorum (Ö4).”

"Herhangi bir eğitim almadım (Ö5)."

Tablo 11.

Medya Okuryazarlığı Dersi Verecek Olan Öğretmenlerin Alması Gereken Eğitim Hakkındaki Görüşler

\begin{tabular}{ll}
\hline & $\mathrm{f}$ \\
\hline \multicolumn{1}{c}{ Görüşler } & Ö \\
\hline Kısa süreli seminerler verilmeli & 2 \\
\hline Uzun süreli ve uygulamalı eğitim verilmeli & 4 \\
\hline Toplam & 6 \\
\hline Ö:Ögrat
\end{tabular}

Ö: Öğretmenler

Tablo 11'de görüldüğü gibimedya okuryazarlığı dersi veren 6 öğretmenin 2'si medya okuryazarlığı dersi verecek öğretmenlere kısa süreli seminerlerle eğitim verilmesi gerektiğini, bu eğitimin de sıkıştırılmış olarak değil zamana yayılarak verilmesi gerektiğini söylerken 4'ü de öğretmenlere uzun süreli ve uygulamalı eğitim verilmesi gerektiğini dile getirmiştir. Aşağıda katılımcıların bu ifadelerinden bir kısmına yer verilmiş̧tir:

"Bu dersi verecek olan ögretmenlerin uzun süreli ve uygulamalı bir eğitim almast gerektiğini düşünüyorum. Bu eğitim uzaktan eğitimle de verilebilir. Ĕgitim her gün peş peşe değil de aralikl olarak haftada bir saat ya da on günde iki saat şeklinde verilebilir. Sikıştırılmış bir eğitim yerine zamana yayılmış bir eğitim verilmeli (Ö̊)."

Medya okuryazarlığı dersi veren öğretmenlerden buders için hazırlanmış olan programı içerik, amaç, kapsam, ders için ayrılan süre bakımından değerlendirmeleri istenmiştir. Ögretmenlerin görüşleri Tablo 12'de sunulmuştur. 
Tablo 12.

Medya Okuryazarlığı Dersi Veren Öğretmenlerin Medya Okuryazarlığı Dersi

Öğretim Programı'na İlişkin Görüşler

\begin{tabular}{ll}
\hline \multicolumn{1}{c}{ Görüşler } & $\mathrm{f}$ \\
\hline Süre yeterli & Ö \\
\hline Program uygulamada yetersiz & 2 \\
\hline Toplam & 4 \\
\hline Ö Ograta & 6
\end{tabular}

Ö: Öğretmenler

Tablo 12'de görüldüğü gibi, görüş bildiren 6 öğretmenin 2'si medya okuryazarlığ dersi için ayrılan süreyi yeterli bulurken 4'ü ise programı uygulama safhasında yetersiz bulduğunu dile getirmiştir. Görüş bildiren 6 öğretmenin 4'ü Medya Okuryazarlığı Dersi Öğretim Programı'na ve dersin işlenişine yönelik medya okuryazarlı̆̆ı dersinde zaman zaman İnkılâp Tarihi dersinin işlenmesi, medya okuryazarlığı dersinin gerektiği gibi işlenememesi, medya okuryazarlığı dersinin ülkemizde uygulanması hususunda sıkıntıların olması, zaman içerisinde medya okuryazarlığı programının içerik olarak güncellenmesine ihtiyaç duyulması, mevcut programın uygulama safhasında yeterli olunmaması gibi eksiklikleri de dile getirmiştir.

"Biz medya okuryazarlığı dersinde zaman zaman inkılâp dersi işliyoruz ancak isteğimiz medya okuryazarliğl dersinin en verimli şekilde işlenmesidir. Dersin içeriğine baktığımızda faydalı kazanımların olduğunu görüyoruz fakat gerektiği gibi medya okuryazarlı̆̆ dersini işleyemiyoruz (Ö2)."

Medya okuryazarlığı dersi veren öğretmenlere budersi alan öğrencilerin medya araçlarıyla ilgili tutum ve tercihlerinde değişimler meydana gelip gelmediği, bu durumla ilgili gözlemlerinin neler olduğu sorulmuştur. Öğretmenlerin görüşleri Tablo 13’te sunulmuştur.

Tablo 13.

Medya Okuryazarlı̆̆ Dersi Veren Öğretmenlere Göre Dersi Alan Öğrencilerin Tutumlarında Meydana Gelen Değişimlere İlișkin Görüşler

\begin{tabular}{lll}
\hline & & $\mathrm{f}$ \\
\hline & Görüşler & Ö \\
\hline Değişim meydana geldi & 4 \\
\hline Değişimleri gözlemleyemiyoruz & 2
\end{tabular}

\section{Ö: Öğretmenler}

Tablo 13'te görüldüğg̈ gibi görüş bildiren 6 öğretmenin 4'ü medya okuryazarlığı dersini alan öğrencilerin medya araçları, olaylar, televizyon programları karşısındaki tutum ve davranışlarında daha seçici olma, eleştirel yaklaşma, sorgulayıcı ve araştırmacı davranma gibi değişimlerin olduğunu ifade etmiştir. Öğretmenlerin 2'si ise öğrencilerin medya araçlarına karş1 tutum ve davranışlarında değişim olup olmadığını, okul ve ders dışındaki gündelik hayatlarını kapsayan zamanlarda gözlemleyemediklerini, gözlem yapabildikleri kadarıyla eğitim seviyesi yüksek aile çocuklarının medya araçlarını kullanma konusunda daha kontrollü olduklarını ve olumsuz davranışlardan uzak durduklarını dile getirmiştir. Aşağıda katılımcıların bu ifadelerinden bir kısmına yer verilmiştir:

"Medya okuryazarlığı dersini aldıktan sonra ögrenciler her şeyi izlememeye başladılar. Artık programları seçerek izliyorlar. Yayınlar hakkında eleştiri yapabilmeye başladılar (Ö3)." 
"Öğrenciler artık okudukları duydukları bilgileri sorguluyor, verilen bilgilerde bir eksiklik ya da fazlalık sezdiklerinde araştırma yoluna gidiyorlar (Ö6)."

\section{Türkçe ve sosyal bilgiler öğretmen adaylarının medya okuryazarlığına ilişkin görüşlerine} dair bulgular

Türkçe ve sosyal bilgiler öğretmen adaylarına öğrenim gördükleri fakültede medya okuryazarlığ 1 dersine dair herhangi bir eğitim alıp almadıkları, aldılar ise bu eğitimi yeterli bulup bulmadıkları sorulmuştur. Öğretmen adaylarının görüşleri Tablo 14'te sunulmuştur.

Tablo 14.

Türkçe ve Sosyal Bilgiler Öğretmen Adaylarının Fakültedeki Medya Okuryazarlığı Eğitimine İlişkin Görüşler

\begin{tabular}{lcccc}
\hline & \multicolumn{3}{c}{$\mathrm{f}$} \\
\hline Görüşler & TÖA & SBÖA & TOPLAM \\
\hline Ders almadik & 15 & 15 & 30 \\
\hline
\end{tabular}

TÖA: Türkçe öğretmen adayları SBÖA: Sosyal bilgiler öğretmen adayları

Tablo 14'te görüldüğü gibi görüş bildiren 30 öğretmen adayının tamamı medya okuryazarlığı dersini almadıklarını söylemiştir. 15 sosyal bilgiler öğretmen adayının 11 ' $\mathrm{i}$ "İnsan İlişkileri ve İletişim” adı altında medya okuryazarlığına dair bilgilere değinildiğini söylemiş, bunu söyleyenlerin 9'u verilen bu eğitimi yeterli bulmamış, 1'i ise verilen eğitimi yeterli bulduğunu dile getirmiştir.

"İnsan iliş̧kileri ve iletişim" adlı bir ders aldık. Medya okuryazarlı̆̆ başllğı altında bir eğitim almadık. Aldı̆̆ımız bu eğitimi de medya okuryazarlĭ̆ için yeterli görmüyorum (SBÖA10).”

15 Türkçe öğretmen adayının 2'si "Sinema ve Edebiyat" dersinde medyaya ilişkin bazı bilgilere değinildiğini, bu sayede medyaya dair fikre ve bilgiye sahip olduklarını, bu eğitimi medya okuryazarlı̆̆ kapsamında yeterli bulmadıklarını, 1 Türkçe öğretmen adayı ise 2015 Türkçe Öğretim Programını incelediklerinde medya okuryazarlığı konusuna değindiklerini söylemiştir. Aşağıda katılımcıların bu ifadelerinden bir kısmına yer verilmiştir:

"Sinema ve Edebiyat" adlı bir dersi seçmeli olarak aldık. Yarım dönemlik bir dersti. Bu dersle medya okuryazarlığına dair bir fikre ve bilgiye sahip olduk ancak bu eğitim yeterlidir diyemem (TÖA25)."

"Maalesef almadık. Sadece 2015 Türkçe öğretim programını inceledim. Kısaca değindik (TÖA28)."

Türkçe ve sosyal bilgiler öğretmen adaylarına medya okuryazarllğg dersinin lisans programlarında ayrı bir ders olarak verilmesi gerektiğini düşünüp düşünmedikleri sorulmuştur. Ögrretmen adaylarının görüşleri Tablo 15'te sunulmuştur.

Tablo 15.

Türkçe ve Sosyal Bilgiler Öğretmen Adaylarına Medya Okuryazarlı̆̆ Programlarında Verilmesine İlişkin Görüşler 


\begin{tabular}{lcccc}
\hline & Görüşler & TÖA & SBÖA & TOPLAM \\
\hline Ayr1 verilmeli & 11 & 12 & 23 \\
\hline Seçmeli verilmeli & 2 & 1 & 3 \\
\hline Görüş bildirmedi & 2 & 2 & 4 \\
\hline Toplam & 15 & 15 & 30 \\
\hline
\end{tabular}

TÖA: Türkçe öğretmen adayları SBÖA: Sosyal bilgiler öğretmen adayları

Tablo 15'te görüldüğü gibi görüş bildiren 30 öğretmen adayının 23'ü lisans programlarında medya okuryazarlığı dersinin ayrı olarak, 3’ü de seçmeli olarak verilmesi gerektiğini dile getirmiştir. 4 öğretmen adayı da konuyla ilgili görüş bildirmemiştir.

"Kesinlikle lisans programlarında medya okuryazarlı̆̆ dersi diğer derslerden ayrı verilmeli (SBÖA2)."

“Günümüzde her türlü bilgiye medya ortamından ulaştığımı için bu konuda kesinlikle bir eğitim olmalı. Eğitimin zorunlu olmasina gerek yok ancak seçmeli de olsa muhakkak bireylere medya okuryazarlı̆̆ e ğitimi verilmeli (TÖA17)."

Türkçe ve sosyal bilgiler öğretmen adaylarına medya okuryazarlığı dersi için medya okuryazarı öğretmenlerin yetiştirilmesinin gerekli olup olmadığı, bu dersin hangi dalın öğretmeni tarafından verilmesi gerektiği ve öğretmenin hangi yeterliliklere sahip olması gerektiği sorulmuştur. Öğretmen adaylarının görüşleri Tablo 16'da sunulmuştur.

Tablo 16.

Türkçe ve Sosyal Bilgiler Öğretmen Adaylarının Medya Okuryazarı Öğretmen Yetiştirilmesine İlişkin Görüşleri

\begin{tabular}{lcccc}
\hline & Görüşler & & $\mathrm{f}$ & \\
\hline & TÖA & SBÖA & Toplam \\
\hline Yetiştirilmeli & 9 & 12 & 21 \\
\hline Gerek yok & 2 & 3 & 5 \\
\hline Kararsizlar & 2 & - & 2 \\
\hline Görüss bildirmeyen & 2 & - & 2 \\
\hline Toplam & 15 & 15 & 30 \\
\hline
\end{tabular}

TÖA: Türkçe öğretmen adayları SBÖA: Sosyal bilgiler öğretmen adayları

Tablo 16'da görüldüğü gibi görüşüne başvurulan 30 öğretmen adayının 21'i medya okuryazarlığı alanında kesinlikle uzman öğreticilerin yetiştirilmesi gerektiğini söylemiştir. Medya okuryazarı öğretmenlerin yetiştirilmesi gerektiğini söyleyenlerin 12'si sosyal bilgiler, 9'u Türkçe öğretmeni adayıdır. Görüş bildirenlerin 5'i uzman öğreticiye gerek olmadığını, 2 Türkçe öğretmen adayı da kararsız olarak uzman öğreticinin olabileceğini dile getirmiştir.

"Kesinlikle medya okuryazarı öğretmenler yetiştirilmeli çünkü ustalık gerektiren bir alan bu (TÖA20).”

"Olabilir de olmayabilir de. Derse iliş̧kin bilgiye sahip olmadiğım için net yanıtlar veremiyorum. Medyayla ilgili bölümlerden mezun kişiler veya medya okuryazarı ögretmenler vermeli (SBÖA14).”

“Olabilir ancak ayrı bir ögretmenin yetiştirilebileceğini düşünmüyorum (TÖA17).”

Tablo 17 
Medya Okuryazarlığı Dersinin Hangi Branşın Öğretmeni Tarafından Verilmesi Gerektiğine Dair Görüșler

\begin{tabular}{lcccc}
\hline & & & $\mathrm{f}$ & \\
\hline & Görüşler & TÖA & SBÖA & Toplam \\
\hline Türkçe öğretmeni & 10 & 2 & 12 \\
\hline Sosyal bilgiler öğretmeni & - & 2 & 2 \\
\hline Diğgr branş öğretmenleri & 5 & 9 & 14 \\
\hline Medya Okuryazarlı̆̆ öğretmenleri & - & 2 & 2 \\
\hline Toplam & 15 & 15 & 30 \\
\hline
\end{tabular}

TÖA: Türkçe öğretmen adayları SBÖA: Sosyal bilgiler öğretmen adayları

Tablo 17'de görüldüğü gibi medya okuryazarllğı dersini ortaokullarda hangi branş öğretmeninin vermesi gerektiğine dair görüş bildiren öğretmen adayının 12'si Türkçe öğretmenlerinin, 2'si sosyal bilgiler öğretmenlerinin, 14'ü ise bu alanda eğitimli diğer branş öğretmenlerinin medya okuryazarlığ dersini verebileceğini dile getirmiştir. 2 öğretmen adayı da medya okuryazarlı̆̆ öğretmenlerinin dersi vermesi gerektiği söylemiştir.

"Türkçe, sinıf ve rehberlik ögretmenleri medya okuryazarlı̆̆ derslerini verebilir (SBÖA9).”

"Sosyal bilgiler ögretmeni bu dersi verebilir (SBÖA15)."

"Ortaokullarda medya okuryazarlı̆̆ dersini Türkçe öğretmenleri verirse dersin daha verimli olacağını düşünüyorum (TÖA26).”

Tablo 18.

Medya Okuryazarlığı Dersini Veren Öğretmenin Hangi Yeterliliklere Sahip Olması Gerektiğine Dair Görüşler

\begin{tabular}{lcccc}
\hline & \multicolumn{2}{c}{ G } & \\
\hline & Törüşler & TÖA & SBÖA & Toplam \\
\hline Analiz, sentez, değerlendirme, problem çözme, sorgulama, eleştiri & 3 & 3 & 6 \\
\hline Alan bilgisi & 4 & 3 & 7 \\
\hline İletişim becerisi & 2 & 2 & 4 \\
\hline Tarafsız bakış açıs1 & - & 4 & 4 \\
\hline Gündem takibi yapan & 1 & 1 & 2 \\
\hline Teknoloji bilgisi & 3 & - & 3 \\
\hline Görüş bildirmedi & 2 & 2 & 4 \\
\hline Toplam & 15 & 15 & 30 \\
\hline
\end{tabular}

TÖA: Türkçe öğretmen adayları SBÖA: Sosyal bilgiler öğretmen adayları

Tablo 18'de görüldüğü gibi görüşü alınan öğretmen adaylarının 6'sı medya okuryazarı öğretmenlerinin problem çözme, araştırma, analiz, değerlendirme, sorgulama, eleştiri yapabilme becerilerine, 7'si medya okuryazarlığıyla ilgili alan bilgisine, 4'ü kolaylıkla iletişim kurabilme becerisine, 4'ü tarafsı olma becerisine, 2'si gündem takibi yapabilme becerisine, 3'ü de teknoloji bilgisine sahip kişiler olması gerektiğini söylerken 4 öğretmen adayı bu konuda görüş bildirmemiştir.

"Dersi verecek olan öğretmenler öncelikle alan bilgisine sahip olmalıdır. Bununla birlikte problem çözme, analiz ve değerlendirme yapabilme yeterliliklerine de sahip olabilmeli (SBÖA1)."

"Medya okuryazarlığıyla ilgili alan bilgisine sahip olmalı (TÖA17)." 
Türkçe ve sosyal bilgiler öğretmen adaylarına medya okuryazarlığ dersinin seçmeli ders olarak ortaokulda okutulması hakkındaki görüşleri sorulmuştur. Öğretmen adaylarının görüşleri Tablo 19'da sunulmuştur.

Tablo 19.

Türkçe ve Sosyal Bilgiler Öğretmen Adaylarının Medya Okuryazarlığı Dersinin Seçmeli Ders Olarak Ortaokulda Okutulması Hakkındaki Görüşleri

\begin{tabular}{lccc}
\hline \multicolumn{1}{c}{ Görüşler } & & $\mathrm{f}$ & \\
\hline Olumludur & TÖA & SBÖA & Toplam \\
\hline Amacını gerçekleştirememektedir & 7 & 6 & 13 \\
\hline Daha erken verilmelidir & 1 & 2 & 3 \\
\hline Dersin verildiğini bilmiyordum & 4 & 7 & 11 \\
\hline Toplam & 3 & - & 3 \\
\hline
\end{tabular}

TÖA: Türkçe öğretmen adayları SBÖA: Sosyal bilgiler öğretmen adayları

Tablo 19'da görüldüğü gibimedya okuryazarlı̆ğ dersinin ortaokullarda seçmeli olarak okutulmasıyla ilgili görüş bildiren öğretmen adaylarının 13'ü bu uygulamaya olumlu bakmaktadır. 30 öğretmen adayının 3'ü genel bağlamda medya okuryazarlığı dersinin boş bir ders olarak algılandığını, derste medya okuryazarlığına ilişkin konuların işlenmediğini, bu ders için ayrılan sürenin başka branș derslerinin tamamlayıcısı olarak kullanıldığını söyleyerek bu dersten fayda sağlanamadığını ve dersin amacını gerçekleștiremediğini ifade etmiștir. Görüş bildiren 11 öğretmen adayı ise medya okuryazarlığı dersinin daha erken yaşlardan itibaren verilmesi gerektiğini dile getirirken 3 Türkçe öğretmen adayı medya okuryazarlı̆̆ 1 dersinin ortaokullarda verildiğinden haberi olmadığını ifade etmiştir.

"Yararlı bir uygulama ancak etkili bir şekilde okullarda uygulandiğını düşünmüyorum. Birçok ögretmen bu dersi işlemiyor bile kendi branş dersinin devamı niteliğinde bu dersi görerek dersi devam ettiriyor. Bu sebepten dolayı medya okuryazarlı̆̆ dersinden fayda sağlanamıyor (SBÖA15)."

"Ben de ortaokulda bu dersi aldım çok da verimli geçtiğini düşünmüyorum, formalite bir ders olduğunu düşünüyorum. Tabi hakkıyla bu dersi işleyen öğretmenler vardır illaki. Ancak genel bağlamda boş bir ders olarak algılandiğını düşünüyorum. Derste başka etkinlikler yapıllyor ya da geçiştiriliyor (TÖA22)."

Türkçe ve sosyal bilgiler öğretmen adaylarına medya okuryazarlığg dersi kapsamında öğrencilere yönelik hangi tutum, davranış ve becerilerin geliştirilmesi gerektiği hakkındaki görüşleri sorulmuştur. Öğretmen adaylarının görüşleri Tablo 20'de sunulmuştur.

Tablo 20.

Öğretmen Adaylarına Göre Medya Okuryazarlığı Dersi Kapsamında Öğrencilerde Geliştirilmesi Gereken Tutum, Davranıș ve Becerilere İlișkin Görüșler

\begin{tabular}{lccc}
\hline \multicolumn{1}{c}{ Görüşler } & \multicolumn{2}{c}{ f } \\
\hline $\begin{array}{l}\text { Analiz, sentez, değerlendirme, eleştirme, araştırma becerisi } \\
\text { Seçici olma }\end{array}$ & 8 & 9 & 17 \\
\hline $\begin{array}{l}\text { Farklı görüşler ( duyarlılık, hoşgörü, özgüven, teknolojik aletleri ve } \\
\text { medya araçlarını kullanma becerisi.) }\end{array}$ & 2 & 3 & 8 \\
\hline Toplam & 3 & 5 \\
\hline
\end{tabular}

TÖA: Türkçe öğretmen adayları SBÖA: Sosyal bilgiler öğretmen adayları 
Tablo 20'de görüldüğü gibi görüşüne başvurulan öğretmen adaylarının 17'si analiz, sentez, değerlendirme, araştırma, eleştirme, karşılaştırma gibi temel beceriler üzerinde durmuştur. Görüş bildiren 30 öğretmen adayının 8'i öğrencilerin medya tarafından sunulan bilgiler karşısında seçici davranma becerisi kazanmaları gerektiğini söylerken 5'i ise öğrencilerde geliştirilmesi gereken beceriler konusunda farklı görüşler ileri sürmüştür. Yazıll, görsel, işitsel teknolojik aletleri faydalı kullanabilme, farklı görüşlere hoşgörülü olma, çevreye karşı duyarlı ve faydalı olma, özgüvenli olma, merak duyma, görsel hafızayı güçlendirme farklı görüşler arasındadır.

“Öğrencilerin özgüven duygusu geliştirilmeli. Böylece ögrencilerin yanlış bulduğu bir olaya, duruma, bilgiye içinden geldiği gibi yorum ve eleştiri yapabilme becerisi gelişstirilmiş olur (TÖA16)."

"Düşünme becerisi geliştirilmeli. Kendi kültürüne örf ve âdetine aykırı olan bilgileri ayırt edebilmeli. Özgür düsünceye sahip olan ve bunu ifade edebilen bireyler olarak yetiştirilmeli (TÖA25)."

Medya okuryazarlığı dersini verecek 15 Türkçe, 15 sosyal bilgiler öğretmen adayı ve bu dersi veren 6 öğretmenle yapılan görüşmeler sonucunda elde edilen bulgular, medya okuryazarlığına yönelik, öğretmenlere ve öğretmen adaylarına yeterli eğitimin verilmediğini, yeterli eğitim almayan ögreticilerin de okullarda medya okuryazarlı̆̆ 1 dersini gerektiği gibi işlemediğini ve medya okuryazarlığı dersinin öğrenciler tarafından önemsenmeyen bir ders olarak algıladığını göstermektedir.

\section{Tartışma / Sonuç ve Öneriler}

Medya okuryazarlığı dersine ilişkin öğrenci tutumlarını belirlemek ve medya okuryazarlığı dersine ilişkin öğretmen ile öğretmen adaylarının görüşlerini tespit etmeyi amaçlayan bu çalışmanın bulgularından yola çıkarak elde edilen sonuçları maddeler hâlinde şu şekilde siralamak mümkündür:

- Medya okuryazarlığı dersini alan ve almayan öğrencilerin medyayı algılama biçimi boyutuna yönelik tutumları arasında anlamlı bir fark olmadığ 1 sonucuna ulaşılmıştır. Dersi alan ve almayan öğrencilerin medyayı algılamaları arasında bir farkın olmaması, medya okuryazarlığı dersinin öğrenciler üzerinde yeterli düzeyde bir etkisinin olmadığını düşündürmektedir.

- Medya okuryazarlığı dersini alan öğrencilerin, öğretmenin dersi işleme biçimini beğendikleri; derste kullanılan araç-gereci, derste kullanılan öğretim yöntemlerini ve sınıf içi etkinlikleri yeterli buldukları belirlenmiştir. Bununla birlikte öğrencilerin grup ortalaması incelendiğinde dersi alan öğrencilerin sınıf içi tartışmaları yeterli bulmadıkları sonucuna ulaşılmıştır.

- Dersi alan öğrencilerin anne ve babalarının da medya okuryazarlı̆̆1 konusunda eğitilmeleri gerektiği ve medya okuryazarlığı dersinin gerekli ve yararlı olduğunu düşündükleri belirlenmiştir. Bununla birlikte öğrenciler, dersin zorunlu olmaması gerektiğini düşünmekte ve dersi almayanlara bu dersi tavsiye etmemektedirler. Öğrenciler tarafından medya okuryazarlığı dersinin en ilgi çekici özelliğinin çok farklı etkinliklerle işlenmesi olduğu belirtilirken öğrencilerin bu dersi zevkli ve eğlenceli bulmadıkları da dersin algılanma biçimi boyutuna ilişkin ulaşılmış başka bir sonuçtur.

- Dersi alan öğrencilerin bu ders sayesinde eleştirel ve seçici davranan daha iyi bir medya okuryazarı olduklarını belirttikleri görülmektedir. Gözlem yeteneklerinin arttığını düşünen öğrencilerin, dersi aldıktan sonra televizyon izleme ve tüketim alışkanlıklarında herhangi bir değişim olmadığını düşündükleri, aileleriyle ve arkadaşlarıyla medya okuryazarlığı dersinde edindikleri bilgileri paylaşmaktan kaçındıkları sonucu da öğrencilerin görüşleri arasında tutarsızlık olduğunu göstermektedir. 
- Medya okuryazarlığı dersini alan ve almayan öğrencilerin medya araçlarını tercih sıraları aynı olup sirasiyla internet, televizyon, dergi, gazete, radyoyu tercih ettikleri belirlenmiştir. İnternet tercihinde dersi alanlar, dergi tercihinde ise dersi almayanlar lehine anlamlı farklılık tespit edilmiştir $(\mathrm{P}<0.05)$. Bu sonuç, Bozkurt'un (2012) sonuçlarıyla uyuşmaktadır. Bozkurt (2012), medya okuryazarlığı dersini alan öğrencilerin medyaya bakışını incelemiş ve medya okuryazarlığı eğitimi alan öğrencilerle bu dersi almayan öğrencilerin kitle iletişim araçlarını kullanım sıklıklarında anlamlı farklılıklar olduğu sonucuna varmıştır. Benzer bir sonuca Oflaz (2016)'ın çalışmasında da rastlanmıştır.

- Medya okuryazarlığı dersi veren öğretmenlere göre medya okuryazarlığı dersinin, öğrencileri iyi bir medya okuryazarı olacak şekilde yetiştirmeye yönelik hedeflerden oluştuğunu düşündükleri ve dersi gerekli gördükleri belirlenmiştir.

- Araştırma sonucunda medya okuryazarlı̆g 1 dersi veren 6 öğretmenin 4'ünün herhangi bir ön hazırlık yapmadan 2'sinin ise bu ders için gereken hazırllğı yaparak derse girdiği sonucuna ulaşılmıştır.

- Araştırmada 6 öğretmenin 5'inin medya okuryazarlığına ilişkin eğitim almadığı, 1 öğretmenin medya okuryazarlığı ile ilgili birkaç günlük seminere katıldığı ve bu semineri faydalı bulmadığ 1 , 6 öğretmenin 2'sinin medya okuryazarlığ 1 dersi verecek öğretmenlere kısa süreli seminerlerle eğitim verilmesi gerektiğini, bu eğitimin de sıkıştırılmış olarak değil zamana yayılarak verilmesi gerektiğini düşündüğü sonucuna ulaşılmıştır. Bu sonuç Şahin'in (2012) sonuçlarıyla örtüşmektedir. Şahin (2012) yapmış olduğu çalışmada medya okuryazarlığı eğitiminin eleştirel, sorgulayıcı, bilinçli öğrenci yapısı vb. gibi birçok farklı bileşeni içeren yapısından ötürü öncelikle bu eğitimi verecek öğretmenlerin medya okuryazarlığı konusunda yeterli düzeyde eğitim almış olması veya eğitilmesi gerektiği sonucuna ulaşmıştır.

- Araştırmada görüş bildiren 6 öğretmenin 2'sinin medya okuryazarlığ dersi için ayrılan süreyi yeterli bulduğu, 4'ünün ise programı uygulama safhasında yetersiz bulduğu sonucuna varılmıştır.

- Araştırma sonucunda, görüş bildiren 6 öğretmenin 4'ü medya okuryazarlığ dersinde zaman zaman İnkılâp Tarihi dersinin işlendiğini, medya okuryazarlı̆̆ 1 dersinin gerektiği gibi işlenmediğini, medya okuryazarlığ 1 dersinin ülkemizde uygulanması hususunda sıkıntıların olduğunu, zaman içerisinde Medya Okuryazarlığı Dersi Öğretim Programı'nın içerik olarak güncellenmesine ihtiyaç duyulduğunu ifade etmiştir. Kutlu'nun (2018) yapmış olduğu çalışmada da araştırma yapılan okullarda medya okuryazarlığı dersinin gerek öğretmenler gerekse yöneticiler tarafindan yeteri kadar önemsenmediğinin görüldüğü, uygulama yapılan okullarda medya okuryazarlığı dersinin müfredatta olduğu fakat uygulamada işlenmediği, medya okuryazarlığı dersinde ya sosyal bilgiler dersi konularının işlendiği ya da Liselere Giriş Sınavı (LGS) hazırlık testlerinin çözüldüğü tespit edilmiştir. Semiz'in (2013) çalışmasında da öğretmenlerin medya okuryazarlığı alan bilgisi bakımından yetersiz oldukları ve Medya Okuryazarlığ Dersi Öğretim Programı'nın güncellenmesi gerektiği sonuçlarına ulaşılmıştır.

- Öğretmenler, öğrencileri okul ve ders dışındaki gündelik hayatlarını kapsayan zamanlarda gözlemleyemedikleri için öğrencilerin medya araçlarına karşı tutum ve davranışlarında değiş̧im olup olmadığını belirtmemişlerdir.

- Türkçe ve sosyal bilgiler öğretmen adayının tamamının lisans eğitiminde medya okuryazarlığı dersi almadığı, 15 sosyal bilgiler öğretmen adayından 11'inin "İnsan İlişkileri ve İletişim" adı altında medya okuryazarlı̆̆ına dair bilgiler edindiği, 11 öğretmen adayının 9'unun ise verilen bu eğitimi yeterli bulmadığı sonucuna ulaşılmıştır.

- Araştırmada görüş bildiren 30 öğretmen adayının 23'ü lisans programlarında medya okuryazarlığ 1 dersinin verilmesi gerektiğini dile getirmişlerdir.

- Araştırmada 30 öğretmen adayının 21'inin medya okuryazarlığı alanında kesinlikle uzman öğreticilerin yetiştirilmesi gerektiğini düşündüğü belirlenmiştir. Ülker (2012) 
Medya Okuryazarlığı Dersi Öğretmen Kılavuz Kitabı'yla Öğretim Programı'nın tutarlılığını değerlendirdiği çalışmasında medya okuryazarlığı dersini verecek öğretmen seçiminde Bilgisayar ve Öğretim Teknolojileri Bölümü mezunlarının yer alması gerektiğini önermiştir.

- Öğretmen adaylarına göre medya okuryazarlığı dersi öğretmenlerinin sahip olması gereken yeterlilikler içerisinde problem çözme, araştırma, analiz, değerlendirme, sorgulama, eleştiri yapabilme becerileri yer almıştır. Bunun yanı sıra görüş bildirenlerin büyük çoğunluğuna göre dersi verecek öğretmenin medya okuryazarlığı ile ilgili alan bilgisine ve tarafsız bakış açısına sahip kişiler olması gerekmektedir. Ayrıca medya okuryazarlığı dersi verecek öğretmenlerin teknoloji ile iç içe, iletişim becerisi gelişmiş, gündemi takip eden kişiler olması gerektiğinin de düşünüldügü görülmüştür. Bu sonuç Kaplan'ın (2017) sonuçlarıyla örtüşmektedir.

- Araştırmada görüş bildiren Türkçe ve sosyal bilgiler öğretmen adaylarından 13'ünün medya okuryazarlığı dersinin ortaokullarda seçmeli olarak okutulmasına olumlu baktığ sonucuna ulaşılmıştır.

- Görüş bildiren 11 öğretmen adayının, medya okuryazarlığı dersinin daha erken yaşlardan itibaren verilmesi gerektiğini düşündüğü belirlenmiştir. Cangin (2014) de çalışmasında öğrencilere medya okuryazarlığı eğitimi ile eleştirel bakış açısı kazandırıldığı ancak eğitimin sürdürülebilir olması için dersin zorunlu olması, 6, 7 ve 8 . sınıflar olmak üzere her sinıfta verilmesi gerektiği sonucuna ulaşmıştır.

- Araştırmada elde edilen sonuçlardan hareketle şu önerilerde bulunmak mümkündür:

- Medya okuryazarlığı ders içeriği ve etkinlikleri yeniden düzenlenmeli, dersler eğlenceli etkinliklerle ve uygulamalarla zevkli hâle getirilmelidir.

- Medyanın, medya araçlarının ve medya iletilerinin yaşamımızın her alanında yer aldı̆̆ı; bundan sonra da yer alacağı düşünüldüğünde medya okuryazarlığı dersinin lisans programlarında daha fazla yer alması gerekmektedir. 2018 yılında öğretmenlik lisans programları yenilenmiştir. Yenilenen 25 lisans programına bakıldığında medya okuryazarlığı dersinin Sosyal Bilgiler Öğretmenliği Lisans Programı'nda zorunlu, diğer lisans programlarında ise seçmeli olarak yer aldığı görülmektedir. Sosyal bilgiler öğretmenliği dışındaki lisans programlarında medya okuryazarlığına genel kültür seçmeli dersleri ve alan eğitiminin seçmeli dersleri içerisinde yer verilmiştir. Lisans programlarında bu dersin artık yer alıyor olması sevindiricidir. Bununla birlikte dersin bütün lisans programına zorunlu ders olarak eklenmesi gerektiği düşünülmektedir.

- Medya okuryazarlığı eğitimi ortaokullarda Türkçe veya sosyal bilgiler nadiren de diğer branş öğretmenleri tarafından verilmektedir. Hâlbuki medya okuryazarlı̆̆ 1 eğitiminin herhangi bir branşın öğretmeni tarafından değil, alanında uzman öğreticiler tarafindan verilmesi gerektiği düşünülmektedir. Şayet herhangi bir branşın öğretmeni bu eğitimi verecekse her branş öğretmeninin medya okuryazarlığı ile ilgili yeterli bilgi ve beceriye sahip olacak şekilde yetiştirilmesi gerekmektedir.

- Ortaokullarda seçmeli olarak verilen medya okuryazarlığı dersinin yapılan araştırmada öğrenciler ve öğretmenler tarafından boş bir ders olarak algılandığg ve bu derste başka derslerin işlendiği görülmektedir. $\mathrm{Bu}$ sebeple öncelikle öğretmenlerin medya okuryazarlığı dersine ve eğitimine yönelik algılarının değiştirilmesi gerekmektedir. Medya okuryazarlığ e eğitiminin önemini öğretmenlere ve öğrencilere kavratıcı çalışmalar ve düzenlemeler yapılmalıdır. Ayrıca medya okuryazarlığı dersi seçmeli değil, zorunlu bir ders hâline getirilmelidir.

- Araştırma sonucunda öğretmenlerin medya okuryazarlığı dersinin öğrenciler üzerindeki etkilerini gözlemlemekte zorlandıkları sonucuna ulaşılmıştır. Bu sebeple yazılı ve görsel medyanın öğrencileri nasıl etkilediğini takip etmeyi kolaylaştırmak için okul, öğretmen, aile ve öğrenci okul içi ve okul dışı etkinliklerde etkileşim ve iş birliği içinde olmalı, eş zamanlı hareket etmelidir. Örneğin ilgili kurumlar tarafindan (MEB, RTÜK, TTK, vb.) 
ailelere, öğretmenlere gözlem, öneri, eleştiri formları hazırlanabilir. Bu formlar uzman kişiler tarafından değerlendirilerek gerekli düzeltmeler ve düzenlemeler yapılabilir.

- Medya okuryazarlığı dersi veren öğretmenlerin bu alanla ilgili yeterli düzeyde eğitim almadıkları, birkaç günlük seminerlerle derse girdikleri ve aldıkları eğitimi yeterli bulmadıkları belirlenmiştir. Bu sebeple dersi verecek öğretmenlere medya okuryazarlığ 1 eğitimi uzman akademisyenler tarafından sürece yayılmış bir şekilde ve öğretmenlerden dönüt alarak gerçekleştirilmelidir.

- Medya okuryazarlığı eğitimi için hazırlanan programlar teorik eğitimden ziyade uygulamalı eğitim mantığına dönük etkinliklerden oluşmalıdır.

- Medya okuryazarlığı eğitiminin öğrencilere sadece 6,7 ve 8 . sinıflarda seçmeli olarak verilmesi yerine hayat boyu öğrenme çerçevesinde ele alınıp zorunlu olarak okul öncesi eğitimden başlanarak sarmal bir şekilde sürdürülmesi gerekmektedir. Çünkü tüm bireylerin medya okuryazarlığ bilgilendirmenin sürece yayılarak ve yaşamın içine yerleştirilerek yapılması faydalı olacaktır.

\section{Etik Kurul Onay Bilgileri}

Araştırmanın, bilimsel araştırma ve yayın etiğine uygunluğu, Giresun Üniversitesi Bilimsel Araştırma ve Yayın Etiği Kurulu'nun 21.04.2020 tarihli 2020-3 karar sayılı toplantısında değerlendirilmiş ve uygunluğu 23.04.2020 tarihli 44079388-050.01.04-E.20974 sayılı ve 36 Sayılı Bilimsel Araştırma ve Yayın Etiği Kararı konulu yazı ile bildirilmiştir.

\section{Kaynaklar}

Aktı, S. (2011). İlköğretim sekizinci sinıf öğrencilerinin medya okuryazarlı̆̆ ile sosyal beceri düzeyleri arasındaki iliş̧kinin belirlenmesi (Yayımlanmamış yüksek lisans tezi). Fırat Üniversitesi Sosyal Bilimler Enstitüsü, Elazı̆g.

Altun, A. (2010). Medya okuryazarllğının sosyal bilgiler programlarlyla ilişkilendirilmesi ve öğretimi (Yayımlanmamıș doktora tezi). Gazi Üniversitesi Eğitim Bilimleri Enstitüsü, Ankara.

Asrak Hasdemir, T. (2012). Gelenekselden yeni medya okuryazarlığına: Türkiye örneğinde bir değerlendirme. Hitit Üniversitesi Sosyal Bilimler Enstitüsü Dergisi, 5(2), 23-40.

Aydeniz, H. (2012). Medyayı tanımak. (2. Baskı). İstanbul: AEP Uygulama ve Yaygınlaştırma Projesi EDAM Eğitim Danışmanlığı ve Araştırmaları Merkezi.

Aytaş, G. ve Kaplan, K. (2017). Medya okuryazarlığı bağlamında yeni okuryazarlıklar. Ahi Evran Üniversitesi Kırşsehir Ĕgitim Fakültesi Dergisi (KEFAD), 18(2), 291-310.

Bacaksız, T. (2010). Medya okuryazarlı̆̆ dersinde gazete ve dergi kullanımı İzmir'de medya okuryazarlı̆̆ dersinin ögrencilerin gazete ve dergi okuma alışkanlıklarına olan etkisi (Yayımlanmamış yüksek lisans tezi). Gazi Üniversitesi Sosyal Bilimler Enstitüsü, Ankara.

Bakan, U. (2010). Illköğretim medya okuryazarlı̆ğ dersinin öğrencilerin eleştirel düsünme becerilerine etkisi (Yayımlanmamış yüksek lisans tezi). Atatürk Üniversitesi Sosyal Bilimler Enstitüsü, Erzurum.

Barışeri, N. (2013). Araştırma yaklaşım ve yöntemleri: Müzik eğitiminde uygulamalı araştırmalar. Sanat Ĕ̈itim Dergisi, 1(1), 1-13.

Barut, E. (2015). Yeni medya okuryazarlı̆̆l, iletişsim becerileri ve demokratik eğilim: Bir yapısal eşitlik modellemesi (Yayımlanmamış yüksek lisans tezi). Süleyman Demirel Üniversitesi Eğitim Bilimleri Enstitüsü, Isparta.

Bilici, İ. E. (2011). Türkiye'de ortaöğretimde medya okuryazarlığ dersi için bir model önerisi. (Yayımlanmamış doktora tezi). Erciyes Üniversitesi Sosyal Bilimler Enstitüsü, Kayseri.

Bozkurt, İ. (2012). Medya Okuryazarllğg dersini alan ögrencilerin medyaya baklşı: Kayseri örneği (Yayımlanmamış yüksek lisans tezi). Selçuk Üniversitesi Sosyal Bilimler Enstitüsü, Konya.

Bütün, E. (2010). Medya okuryazarll̆̆̆ dersine ilişkin öğretmen, ögrenci ve veli görü̈sleri (Samsun ili örneği) (Yayımlanmamış yüksek lisans tezi). Ondokuz Mayıs Üniversitesi Sosyal Bilimler Enstitüsü, Samsun.

Cangin, S. Ş. (2014). İlköğretim öğrencilerinin medya okuryazarlı̆̆ dersine bakış açıları (AnkaraKeçiören örneği) (Yayımlanmamış yüksek lisans tezi). Atatürk Üniversitesi Sosyal Bilimler Enstitüsü, Erzurum. 
Coşkunserçe, S. (2007). Medya ile yaşamayı öğrenmek. Ankara: Son Nokta Yayıncılık.

Creswell, J. W. ve Plano Clark, V. L. (2015). Karma yöntem araştırmaları tasarımı ve yürütülmesi. (2. Baskı). (Y. Dede ve S. B. Demir, çev. ed.). Ankara: Anı Yayıncılık.

Çakır, H., Koçer, M. ve Aydın, H. (2012). Medya okuryazarlığı dersini alan ve almayan ilköğretim öğrencilerinin medya izleme davranışlarındaki farklılıkların belirlenmesi. Selçuk İletişim Dergisi, 7(3), 42-54.

Çiftçi Yeşiltuna, D. (2015). Iletişsim ve medya. Ankara: Nobel Akademik Yayıncılık.

Çinelioğlu, G. (2013). Sosyal bilgiler ögretmen adaylarının medya okuryazarlı̆̆ dersine yönelik tutumlarının incelenmesi (Yayımlanmamış yüksek lisans tezi). Balıkesir Üniversitesi Sosyal Bilimler Enstitüsü, Balıkesir.

Elma, C., Kesten, A., Dicle, A. N., Mercan, E., Çınkır, Ş. ve Palavan Ö. (2009). İlköğretim 7. sınıf öğrencilerinin medya ve medya okuryazarlığı dersine ilişkin tutumları. Ondokuz Mayls Üniversitesi Ĕ̈itim Fakültesi Dergisi,27, 93-113.

Erdem, C. (2018). Dünyada ve Türkiye'de medya okuryazarlı̆̆ eğitimi. Eğitim bilimlerinde akademik araştırmalar (Ed: G. Mıhladız), 409-424, Ankara: Gece Kitaplığı.

Görgülü Aydoğdu, A. (2015). Eleştirel farkindalık yaratmada yeni medya okuryazarlığı ve yeni medya bilinci üzerine bir inceleme (Yayımlanmamış doktora tezi). Gazi Üniversitesi Sosyal Bilimler Enstitüsü, Ankara.

Görmez, E. (2014). Ortaokul öğrencilerinin Medya okuryazarlığı düzeyleri (Yayımlanmamış doktoratezi). Atatürk Üniversitesi Eğitim Bilimleri Enstitüsü, Erzurum.

Işkın, P. (2015). Öğretmen görüşlerine göre yeni medya okuryazarlı̆̆ programı (Yayımlanmamış yüksek lisans tezi). Ondokuz Mayıs Üniversitesi Eğitim Bilimleri Enstitüsü, Samsun.

İnal, K. (2009). Medya okuryazarllğ̆ el kitabı. Ankara: Ütopya Yayınevi.

İnan, T. (2013). Medya okuryazarlığı sürecinde medya, çocuk ve ebeveyn ilişkisi: Ortaokul öğrencilerinin ve ebeveynlerinin televizyon ve internet kullanımlarına ilişkin tutum ve davranışlarının incelenmesi (Yayımlanmamış doktora tezi). Dumlupınar Üniversitesi Eğitim Bilimleri Enstitüsü, Kütahya.

İnceoğlu, Y. (2005). Medyayı doğru okumak. 1. Uluslararası Medya Okuryazarlı̆̆ Konferansı'nda Sunulan Bildiri, Marmara Üniversitesi. 23-25 Mayıs, İstanbul.

Kaplan, K. (2017). Medya okuryazarlı̆̆ dersinin Türkçe öğretimiyle birleştirilmesi sürecinde medya okuryazarlığ dersi ögretmenlerinde bulunması gereken yeterlikler (Yayımlanmamış doktora tezi). Gazi Üniversitesi Eğitim Bilimleri Enstitüsü, Ankara.

Karataş, A. (2017). Öğretmen adaylarının medya okuryazarllk düzeylerinin belirlenmesi ve eğitim fakültelerine yönelik bir "medya okuryazarlı̆̆ı" eğitim programı tasarısı (Yayımlanmamış doktora tezi). Gazi Üniversitesi Eğitim Bilimleri Enstitüsü, Ankara.

Kazan, H. ve Balkın, A. (2018). Geçmişten günümüze medya okuryazarlığı eğitiminin tarihsel dönüşümü: Türkiye örneği. 6. Uluslararası Ĕgitim Programları ve Ögretim Kongresi. 11-13 Ekim, Kars.

Keleş, M. (2013). Eleştirel pedagoji bağlaminda medya okuryazarlığı dersinin işleniş biçiminin incelenmesi (Yayımlanmamış yüksek lisans tezi). Atatürk Üniversitesi Sosyal Bilimler Enstitüsü, Erzurum.

Koçak, B. (2011). İlköğretim yedinci ve sekizinci sınıf öğrencilerinin medya okuryazarlığı dersine ilişkin algiları (Erzurum ili örneği) (Yayımlanmamış yüksek lisans tezi). Atatürk Üniversitesi Eğitim Bilimleri Enstitüsü, Erzurum.

Kutlu, M. (2018). Medya okuryazarlğ̆ dersi kapsamında benimsenen yaklaşımlar ve uygulamalardaki aksaklıklar: Kayseri örneği (Yayımlanmamış yüksek lisans tezi). Erciyes Üniversitesi Sosyal Bilimler Enstitüsü, Kayseri.

Millî Eğitim Bakanlığı [MEB] (2013). Ortaokul ve imam hatip ortaokulu medya okuryazarlığı dersi ögretim programi. Ankara.

Millî Eğitim Bakanlığı [MEB] (2018). Medya okuryazarlı̆̆ı dersi ögretim programı (Ortaokul ve İmam Hatip Ortaokulu 7 veya 8. Siniflar). Ankara.

Najaflı, M. (2018). Ortaöğretim ögrencilerinin TV izleme alışkanlıklarının medya okuryazarlığ bağlamında incelenmesi: Azerbaycan örneği (Yayımlanmamış yüksek lisans tezi). Erciyes Üniversitesi Sosyal Bilimler Enstitüsü, Kayseri.

Naza, C. (2014). Ortaokul öğrencilerinin medya okuryazarlı̆̆ dersine iliş̧kin tutumları (Yayımlanmamış yüksek lisans tezi). Muğla Sitkı Koçman Üniversitesi Eğitim Bilimleri Enstitüsü, Muğla.

Oflaz, T. (2016). Medya okuryazarlı̆̆ dersi kapsamında öğrencilerin, medyaya bakış açılarının değerlendirilmesi: Denizli il örneği (Yayımlanmamış yüksek lisans tezi). Yaşar Üniversitesi Sosyal Bilimler Enstitüsü, İzmir. 
Okuroğlu, M. S. (2016). Eleştirel medya okuryazarlı̆̆ kuramı: Eskişehir okulları ölçeğinde bir alan araştırması (Yayımlanmamış doktora tezi). Anadolu Üniversitesi Sosyal Bilimler Enstitüsü, Eskişehir.

Özdemir, K. (2015). Türkiye'de medya okuryazarlı̆̆ ve ögretim materyalleri 2014 yılı medya okuryazarlı̆̆ materyalinin incelenmesi (Yayımlanmamış yüksek lisans tezi). Anadolu Üniversitesi Sosyal Bilimler Enstitüsü, Eskişehir.

Radyo ve Televizyon Üsst Kurulu [RTÜK]. Medya okuryazarlı̆̆ nedir? Erişim adresi: https://www.medyaokuryazarligi.gov.tr/menu_goster.php?Guid=B7AA7732-1593-4B32BDE5- D76E64C2A5FA\&MenuId=2

Radyo ve Televizyon Üst Kurulu [RTÜK]. Türkiye'de medya okuryazarliğı. Erişim adresi: https://www.medyaokuryazarligi.gov.tr/menu_goster.php?Guid=E56CE034-6CEB-41AEA12C-B618EBEA461B\&MenuId=2

Sadrıu, S. (2009). Seçmeli medya okuryazarlı̆̆ dersi alan ilköğretim ikinci kademe öğrencilerinin ders sonu çıktılarına yönelik bir "pilot araştırma" (Yayımlanmamış yüksek lisans tezi). İstanbul Üniversitesi Sosyal Bilimler Enstitüsü, İstanbul.

Sayın, H. (2015). Medya okuryazarlı̆̆ becerilerinin ortaokul Türkçe programı içerisindeki yeri ve ögrencilerin medya metinleri üretme becerilerinin değerlendirilmesi (Yayımlanmamış yüksek lisans tezi). Erciyes Üniversitesi Eğitim Bilimleri Enstitüsü, Kayseri.

Semiz, L. (2013). Ortaokul ögrencilerinin medya okuryazarlı̆̆ yeterlikleri ve medya okuryazarlığı dersini yürüten öğretmenlerin karşılaştıkları sorunlar (Yayımlanmamış yüksek lisans tezi). Recep Tayyip Erdoğan Üniversitesi Sosyal Bilimler Enstitüsü, Rize.

Sivritepe, S. (2014). Öğrencilerin medya okuryazarlı̆̆ dersine bakışı: Konya ili örneği. (Yayımlanmamış yüksek lisans tezi). Selçuk Üniversitesi Sosyal Bilimler Enstitüsü, Konya.

Şahin, M. (2012). Medya okuryazarlı̆̆ dersi alan ve almayan ilköğretim okulu ögrencilerinin medya tüketim alışkanlıkları farklılaşması. (Yayımlanmamış yüksek lisans tezi). Marmara Üniversitesi Sosyal Bilimler Enstitüsü, İstanbul.

Tan, O. (2015). Medya okuryazarlı̆̆l ĕgitimi: Öğrenci, ögretmen, aile bağlamında örnek bir araştırma (Yayımlanmamış doktora tezi). Akdeniz Üniversitesi Sosyal Bilimler Enstitüsü, Antalya.

Taşkıran Öncel, N. (2007). Medya okuryazarlığına giriş. (2. Baskı). İstanbul: Beta Yayınları.

Tatar, İ. (2016). Ögretmen adaylarının medya okuryazarlığ ile çevrimiçi bilgi arama stratejileri arasındaki ilişskinin incelenmesi (Yayımlanmamış yüksek lisans tezi). Anadolu Üniversitesi Eğitim Bilimleri Enstitüsü, Eskișehir.

Tokgöz, O. (2010). Temel gazetecilik. (8. Bask1). İstanbul: İmge Kitabevi Yayınları.

Türkoğlu, N. (2004). Illetişim bilimlerinden kültürel çalışmalara toplumsal iletişim tanımlar, kavramlar, tartışmalar. İstanbul: Babil Yayınları.

Türnüklü, A. (2000). Eğitimbilim Araştırmalarında Etkin Olarak Kullanılabilecek Nitel Bir Araştırma Tekniği: Görüşme. Kuram ve Uygulamada Ĕ̈itim Yönetimi, 6(4), 543-559.

Ulusoy, A. (2018). Dijital medya okuryazarlı̆̆l, gereksinimler ve yenilikçi uygulamalar üzerine bir inceleme (Yayımlanmamış doktora tezi). Erciyes Üniversitesi Sosyal Bilimler Enstitüsü, Kayseri.

Ülker, M. (2012). Medya Okuryazarlığı dersi öğretmen kılavuz kitabının öğretim programı ile tutarlılı̆̆ının değerlendirilmesi (Yayımlanmamış doktora tezi). Gazi Üniversitesi Eğitim Bilimleri Enstitüsü, Ankara.

Yıldırım, A. ve Şimşek, H. (2013). Sosyal bilimlerde nitel araştırma yöntemleri. (9. Baskı). Ankara: Seçkin Yayınevi.

Yıldırım, Ş. (2017). Türkçe ve sosyal bilgiler öğretmenlerinin medya okuryazarlı̆̆ı ĕ̆itimi ile ilgili becerileri ve görüşleri (Yayımlanmamış yüksek lisans tezi). Yüzüncü Yıl Üniversitesi Eğitim Bilimleri Enstitüsü, Van.

\section{Extended Abstract}

\section{Introduction}

Today, with the technological developments, exposure to visual and audio multimedia messages such as TV programs, internet, mobile phones, cinema and radio bulletins as a society more than ever, causes Media Literacy to be a vital value for 21 st century people. This level of sophistication in the era, technological innovations brought by the era and the diversity of media tools require 
individuals to understand these tools and have the ability to respond to messages. The name of this requirement is "Media Literacy".Media Literacy contributes to the individual in reading and making sense of the media and media messages correctly. In order to correctly understand and use the messages given by the media, it is necessary to receive decent Media Literacy education. The development of the relationship between communication types and the society consisting of many masses, its historical background and all the studies in this field make it compulsory for us to understand this structure and make the necessary analysis in which it is not possible to change its operation in a short time. Therefore, the Ministry of National Education has decided to apply Media Literacy as an elective course in secondary schools in 2007-2008 Education Year. With the implementation of this decision, innovation and development are needed in the situation that arises. It is important to identify deficiencies and to works proceed according to the age keep the studies neoterically.In Turkey in recent years, scientific studies about media literacy significantly increased. When the studies on Media Literacy are examined: There are studies in which media literacy levels of students are examined, studies are carried out to determine teacher and student attitudes towards media literacy, and media literacy programs are examined. However, it has been determined that the studies covering all these aspects of the program on Media Literacy (program, student, teacher candidate, teacher) are limited. For this reason, in this study, it is it was considered necessary to study on secondary school students, teachers who teach the lesson and teacher candidates who are expected to teach the lesson, and are tried to be handled the sources of possible problems related to the Media Literacy course as a whole.

\section{Method}

This study, which aims to determine student attitudes towards the Media Literacy course and to determine the opinions of teachers and prospective teachers regarding the Media Literacy course, is designed with a mixed model in which quantitative and qualitative research methods are used together. The study group, in which the quantitative data of the research is collected, consists of 153 eighth grade students who took the Media Literacy course of 5 secondary schools in the province of Giresun in the 2017-2018 academic year, and 103 seventh grade students who did not take the Media Literacy course A total of 256 students participated in the research. The study group, in which the qualitative data is collected, consists of 5 social studies and 1 Turkish teacher working at the schools where elective Media Literacy course is taught, and 15 Turkish and 15 Social Studies teacher candidates at Giresun University Faculty of Education. In the quantitative part of the research, "Media Literacy Attitude Scale" was used to determine whether there is a semantic relationship between the attitudes and attitudes of the students who took and did not take the elective Media Literacy course. In the qualitative part of the research, "Personal Information Form" and "Interview Form" were used to determine the opinions and information of teachers and prospective teachers related to Media Literacy. The SPSS 16.0 program was used to analyze the quantitative data collected in the study, which aims to determine the levels of secondary school students on Media Literacy. In the analysis of qualitative data, the data collected through interviews were analyzed by content analysis.

\section{Result and Discussion}

It is concluded that there was no significant difference between the attitudes of students who took and did not take the Media Literacy course towards their perception of media. It is determined that the students who took the course of Media Literacy liked the way the teacher taught the lesson, found the tools and materials used in the lesson, the teaching methods used in the lesson and in-class activities sufficient. It is determined that the parents of the students who took the course should also be educated about Media Literacy and they thought that the Media Literacy course was necessary and useful. However, students do not recommend this course to those who think that the course should not be compulsory and those who do not take it. It is observed that the students taking the course stated that they are a better media literate acting critically and selectively thanks to the Media Literacy course. It is determined that the students who took the Media Literacy course and did not, prefer the media tools and prefer internet, television, 
magazines, newspapers and radio respectively. A semantic difference is determined in countenance of those who took the course in Internet preference and those who did not take the course in magazine preference.

According to the teachers teaching Media Literacy, it is determined that they thought that the Media Literacy course consisted of goals aimed at educating students to become a good media literate. As a result of the research, it was concluded that 4 of the 6 teachers who gave Media Literacy lesson entered the lesson by making the necessary preparations for the Media Literacy lesson without any preparation. In the research, it is concluded that 5 of the 6 teachers did not receive any training on Media Literacy, 1 teacher attended a few days seminar on Media Literacy and did not find this seminar useful. In the study, it is concluded that 2 of the 6 teachers who provided opinions found the time allocated for the Media Literacy course sufficient and 4 found the program inadequate in the implementation phase. As a result of the research, 4 of the 6 teachers who give opinions stated that the history course is taught in the Media Literacy lesson, the Media Literacy lesson was not handled properly, there was a need to update the Media Literacy program as a content in time.

It is concluded that not all Turkish and Social Studies teacher candidates have taken Media Literacy courses in undergraduate education. 23 of 30 teacher candidates who expressed their opinions stated that Media Literacy cource should be given in undergraduate programs. In the study, it is observed that 21 out of 30 teacher candidates thought that specialist teachers should be trained in the field of Media Literacy. According to teacher candidate, the skills that media literate teachers should have include problem solving, research, analysis, evaluation, questioning and criticism.

Based on the results obtained in the research, it is possible to make the following recommendations:

- Media Literacy course content and activities should be rearranged, and lessons should be made enjoyable with fun activities and applications.

- It is considered that the Media Literacy course should be included more in the undergraduate programs.

- Media Literacy education is thought to be given not by teachers of any branch but by specialist teachers.

- Medya Media Literacy training for the teachers who will give the lesson should be carried out by expert academicians throughout the process and by receiving feedback from teachers.

- Programs prepared for Media Literacy education should consist of activities for logic of applied education rather than theoretical education.

- Media Literacy education should be handled in a lifelong learning framework rather than being given to students only in the 6th, 7th and 8th grades, and should be continued in a spiral manner, starting with pre-school education. 